\title{
A construção do espaço cívico: monumentos e rituais de memória na Natal republicana (1902-1922)
}

The construction of civic space: monuments and rituals of memory in republican $\mathrm{Na}^{-}$ tal (1902-1922)

http://dx.doi.org/10.1590/1982-02672019v27e07

\section{HELDER DO NASCIMENTO VIANA}

hitps://orcid.org/0000-0003-3578-870X

Universidade Federal do Rio Grande do Norte / Natal, RN, Brasil

RESUMO: $\bigcirc$ artigo analisa o processo de formação do espaço cívico na cidade de Natal entre 1902 e 1922. Procura compreender o papel central dos historiadores locais e do Instituto Histórico e Geográfico do Rio Grande do Norte na construção de uma memória pública republicana por meio do agenciamento de artefatos, da ressignificação de locais públicos e da prática dos rituais cívicos. A pesquisa visa compreender como a nomeação e renomeação de ruas e logradouros, a criação de praças, o entalhamento e a instalação de estátuas, bustos, lápides, hermas e quadros, a identificação de "sítios históricos" e o estabelecimento de espaços edificados para abrigar relíquias e "objetos históricos" colecionados, bem como as celebrações históricas de personagens e de acontecimentos dignos de nota foram importantes na construção de uma identidade coletiva na qual a consciência histórica deveria ter um lugar relevante.

PALAVRAS-CHAVE: Memória Pública. Espaço Cívico. Monumentos. Identidade Cultural.

ABSTRACT: This article analyzes the formation process of civic space in Natal between 1902 and 1922. We seek to comprehend the central role of local historians and of Instituto Histórico e Geográfico do Rio Grande do Norte Historical and Geographical Institute of Rio Grande do Norte) in the construction of a public republican memory through the assemblage of artifacts, the attribution of new meanings to public sites and the practice of civic rituals. This research aims to understand how the practice of naming and renaming streets and public parks, creating squares,

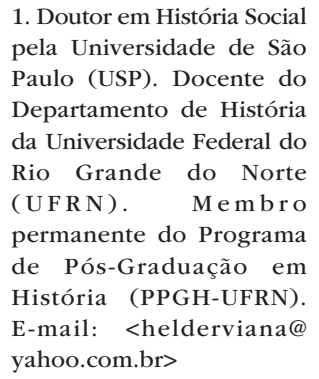

1. Doutor em História Social pela Universidade de São Paulo (USP). Docente do Departamento de História da Universidade Federal do Rio Grande do Norte (UFRN). Membro permanente do Programa de Pós-Graduação em História (PPGH-UFRN). E-mail: <helderviana@ yahoo.com.br> 
the carving and installation of statues, busts, tombstones, hermas and paintings, the identification of "historical sites" and the construction of places built to house collected relics and "historical objects", as well as for the historical celebration of noteworthy characters and events that were important when constructing a collective identity in which the historical consciousness should have a critical role.

KEYWORDS: Public Memory. Civic Space. Monuments. Cultural Identity. 
Com a instalação da República no Rio Grande do Norte, o novo regime procurou imprimir mudanças não só na estrutura política, em estrito senso, mas sobretudo na vida cotidiana da população da capital do estado. Nesse aspecto, o espaço urbano de Natal foi profundamente modificado por meio da nomeação e renomeação de ruas e logradouros, da criação de praças, do entalhamento e da instalação de estátuas, bustos, lápides, hermas e quadros. Também buscou-se identificar "sítios históricos" e estabelecer espaços edificados para abrigar relíquias e "objetos históricos" colecionados. Essas práticas seriam acompanhadas pela celebração cívica de personagens e de acontecimentos dignos de nota.

Este trabalho se inscreve nas reflexões sobre memória pública, aqui entendida como a memória compartilhada por uma coletividade e que proporciona a essa coletividade um senso de identidade comum. ${ }^{2}$ É por meio de uma rede de memória que certos indivíduos compartilham eventos, lugares e legados e, assim, ajudam a criar um coletivo, um "nós", uma "comunidade imaginada" particular. John Bodner considera a memória pública como "um corpo de crenças e ideias sobre o passado que ajudam um público ou uma sociedade a entender tanto seu passado, quanto seu presente e, por implicação, seu futuro". ${ }^{3}$

Essa memória pública se manifesta por discursos, monumentos, museus e eventos comemorativos, sendo todos eles públicos e visíveis. É por esses meios que ela assume sua forma expressiva, pois pressupõe um trabalho interpretativo dos participantes. No entanto, conforme observaram Matthew Houdek e Kendall Phillips, ${ }^{4}$ muito mais do que um consenso, a memória pública é marcada por diferentes modos de interpretação que resultam de tensões e conflitos sociais no interior de dada coletividade. Assim, a definição pública do passado controverso é uma chave importante para entender como as relações de poder são articuladas e compostas dentro de um contexto social, local ou nacional.

Algumas correntes teóricas procuraram explorar a relação entre poder e memória, buscando compreender como grupos e classes sociais operam na produção de uma memória oficial. Eric Hobsbawm e Terence Ranger analisam algumas tradições políticas e culturais existentes na Europa, a fim de demonstrar que se tratavam de manifestações "inventadas". Mais do que um ato natural, a memória implicaria processos de recordação, tradução, esquecimento e ausência que refletem interesses e visões de mundo das classes sociais envolvidas. ${ }^{5}$ Para Michel Foucault, as relações entre poder e memória não estariam necessariamente nos limites das classes sociais, mas dispostas de forma circular numa rede de relações sociais que extrapolaria os interesses de classes particulares. A memória seria tratada como uma "formação discursiva", ou seja, como "uma troca de ideias na esfera pública, mediante a qual certas questões, agendas e definições são
2. Cf. Houdek; Phillips (2017).

3. Bodner apud Light; Young (2015, p. 234, tradução do autor).

4. Houdek; Phillips, op. cit.

5. Hobsbawm apud (2007, p. 10). 
6. Foucault apud Peralta, op. cit., p. 12.

7. Ibid.

8. Bodnar apud Peralta, op. cit., p. 15.

9. Dickinson; Blair; Ott (2010).

10. Tuan (2013, p. 216).

11. Nora (1993). estabelecidas como resultado das lutas de poder entre os participantes nesse discurso". 6

Conforme observou Elsa Peralta, ${ }^{7}$ os estudos mais recentes têm apontado para a multiplicidade da invenção das tradições e a multivocalidade das memórias, especialmente quando essas são consideradas na esfera pública em sociedades democráticas. Em seu trabalho sobre a memória pública nos Estados Unidos do século XX, John Bodnar demonstrou o caráter dual da memória pública, ao mesmo tempo multivocal e hegemônica. Sua construção seria resultado de uma negociação entre narrativas e discursos que expressam muitas vezes interesses opostos. Trata-se de "um processo dinâmico que envolve um debate constante entre a criação, a preservação, a erradicação e a consensualização de memórias". ${ }^{8}$

Estudiosos como Greg Dickinson, Carole Blair e Brian OHt9 chamaram a atenção para o fato de que a compreensão da memória pública passa necessariamente pelo estudo dos seus lugares e retóricas. De fato, entre as operações da memória pública estaria o processo de diferenciação dos lugares ("locais") que implantam e implementam o espaço, ao passo que as memórias, ao serem diferenciadas ("eventos"), marcam, pelo reconhecimento, uma sucessão temporal indiferenciada de ocorrências. Desde os trabalhos pioneiros de Halbwachs ficou demonstrado como as memórias precisam de ancoragem espacial; para isso, locais tornam-se partes de sua construção.

O geógrafo Yi-Fu Tuan, ${ }^{10}$ assim como outros estudiosos, já havia ressaltado o papel das experiências no espaço capaz de transformar ideias abstratas em lugares concretos. Ao discutir o sentido de Estado-nação, Tuan demonstra que, perante a impossibilidade de os sujeitos sociais concretos experienciarem uma noção tão ampla como essa, recorreu-se a meios simbólicos (inclusive locais) como espaços fundamentais de interação social. Ele afirma que o processo de simbolização de determinados locais, sobretudo através da "sacralização", constitui-se como um meio produtor da identidade nacional. Conforme notou nos Estados Unidos, lugares como o Independence Hall na Filadélfia, o santuário do general Lee em Lexington e os imponentes monumentos da cidade de Washington, devido à sua materialidade desempenham um papel importante no sentimento nacional, muito além do domínio das ideias políiticas. É possível tomar tais espaços por aquilo que Pierre Nora denominou de lieux de memoire, ${ }^{11}$ um conjunto de lugares e objetos capazes de armazenar vestígios da memória coletiva. $\bigcirc$ surgimento desses lieux ganha feições na forma de museus, memoriais, arquivos, centros de preservação, monumentos, figuras históricas, entre outros. Eles seriam responsáveis por assinalar um momento novo, constitutivo da modernidade, em que a memória já não seria produzida e compartilhada pelos indivíduos cotidianamente, mas como uma 
manifestação residual exclusiva a esses espaços especializados. A ideia de lugares de memória estaria ligada ao fato de a memória se encontrar agora exteriorizada, artificializada, como algo sem originalidade ou espontaneidade, mas como produto de dispositivos especializados. ${ }^{12}$

reconhecimento desses lieux de memoire não está associado apenas aos locais, em estrito senso, mas ao domínio dos objetos materiais em geral. As coisas sempre foram importantes suportes da memória. A ligação dos objetos materiais à memória esteve presente nas reflexões sobre como conhecemos o passado. Entre os estudiosos desta problemática, o geógrafo David Lowenthal ${ }^{13}$ tomou a noção de relíquia como chave para pensar a relação de determinados objetos com o passado e seu papel como suporte da memória. A relíquia é definida pelo geógrafo como um conjunto de objetos ou vestígios físicos que desempenham um papel de guia autônomo para épocas remotas. Entretanto, esse sentido só pode ser desvendado a partir de uma forma de pensamento capaz de estabelecer os pontos entre o objeto no presente e o passado de onde ele veio. Conforme assinalou Lowenthal:

Todas as relíquias existem simultaneamente no passado e no presente. $\bigcirc$ que nos leva a identificar as coisas como antiquadas ou antigas varia de acordo com o meio ambiente e a história, com o indivíduo e a cultura, com a perspectiva e percepção histórica. ${ }^{14}$

Sem dúvida, entre as espécies de artefatos que povoam nosso mundo material, os monumentos são os que mais guardam relação com a memória coletiva. Eles podem ser definidos como artefatos erguidos por um conjunto de indivíduos com a finalidade de comemorar ou fazer que futuras gerações relembrem eventos ou personalidades determinadas do passado, invocando seus sacrifícios, crenças, atitudes ou condutas excepcionais. É essa operação de proclamar determinado fragmento do passado que torna os monumentos um meio importante de influenciar a memória e, ao mesmo tempo, delimitar a identidade da comunidade a eles associada. Marija Kulišić e Miroslav Tudman ${ }^{15}$ assinalam que, embora estejam fixos no espaço e no tempo, os monumentos são objetos de comunicação. Sendo assim, atuam ativamente nos eventos sociais.

Desde as últimas décadas do século XIX, os monumentos se apresentam como artefatos importantes na construção da simbologia urbana. Essa relação entre monumentos e espaço urbano tem sido uma das questões mais exploradas pelos estudiosos da memória coletiva. Diversos deles procuraram localizar os monumentos no espaço público e seu papel na afirmação, ou mesmo no protesto, de uma unidade compartilhada no processo de construção da identidade nacional. ${ }^{16}$
12. Cf. Meneses (2009).

13. Lowenthal (1998)

14. Ibid., p. 154.

15. Kuli?i?; Tudman (2009).

16. Cf. Bodnar (1994); Johnson (1995); Mitchell (2003). 
17. Meneses (2009) atenta para o fato de que tais mudanças estiveram associadas à substituição da figura do pedestre, sujeito ativo da percepção espacial, pela do transeunte, que se caracteriza por uma percepção $\mathrm{ma}$ is empobrecida do espaço, com ações voltadas muito mais para transpor e até eliminar o espaço transitado.

18. Connerton (1993).

19. Ibid., p. 49

20. Algumas dessas práticas não foram exclusivas do contexto republicano. Já no período pós-Independência encontramos cerimônias de caráter cívico no Rio de Janeiro que desempenharam um papel social importante na formação do sentimento de identidade nacional. $\mathrm{Cf}$. Kraay (2008).
No entanto, antes de tomar os monumentos como possuidores de significados intrínsecos e permanentes, é necessário compreender a produção do seu sentido, sua utilização e as relações de poder a eles associadas a partir de contextos historicamente definidos. Assim, ao compreender as transformações operadas no espaço urbano, sobretudo no pós-Segunda Guerra Mundial, o historiador Ulpiano Meneses chamou atenção para a redução dos lugares públicos e o declínio do monumento cívico nesse espaço. Mais do que mudanças conjunturais, essas transformações parecem assinalar uma fragmentação social e um desenraizamento da memória coletiva. ${ }^{17}$

Por fim, é fundamental ressaltar o papel desempenhado pelas performances rituais na transmissão de imagens e conhecimento do passado. Festas, comemorações, desfiles, são performances rituais ou estão sujeitas a elas. Assim, é por meio de um trabalho corporal, intencional ou não, que a memória se torna sedimentada no corpo. Para Paul Connerton, ${ }^{18}$ o trabalho de memória seria resultado não só de um processo de "inscrição", ou seja, oriundo da transmissão de informações por dispositivos como textos talhados ou impressos, fotografias, fitas cassetes, computadores e outros meios de armazenamento e recuperação da informação, mas também derivaria de um processo de "incorporação". Este último seria uma prática comunicativa realizada pela própria atividade corporal que, por meio da incorporação de gestos, posturas e comportamentos, desempenha um papel fundamental de produção da memória. Assim, o poder comemorativo do rito estaria para além de sua capacidade mnemônica - ou seja, a de permitir que seus participantes recordem determinados acontecimentos míticos -, abarcando também a possibilidade oferecida pela experiência cerimonial de reapresentar o passado por meio de uma corporização. Através de cerimônias que relatavam acontecimentos do passado, seus participantes reapresentavam, por diversas vezes, a realidade transfigurada do mito, ao mesmo tempo que todos "aqueles que tomavam parte no culto se tornavam, por assim dizer, contemporâneos do acontecimento mítico". ${ }^{19}$

Conforme veremos, as experiências aqui estudadas assumiram caráter expressivo no cotidiano da população da capital potiguar, apontando para a importância dos ideais cívicos na definição da cidadania republicana, ao mesmo tempo que procuraram admitir a existência de um espaço específico de expressão da vida política e social na cidade. ${ }^{20}$

Algumas dimensões dessas mudanças se tornam mais claras quando comparadas com as antigas formas identitárias herdadas da sociedade escravocrata, católica e monarquista oitocentista, testemunhando o declínio de práticas centenárias de religiosidade, como lapinhas, presépios, novenas e procissões, ou mesmo das cerimônias de evocação da realeza, como as 
comemorações de aniversários dos membros da família real. ${ }^{21}$ Entre essas antigas configurações de identificação cultural estavam aquelas baseadas em referências geográficas do território urbano.

Até o final do século XIX, a cidade de Natal era formada por dois lugares distintos: a Cidade Alta, onde havia sido instalado seu núcleo fundador, e a Ribeira, a qual se estabeleceu a partir do fluxo comercial das primeiras décadas do século XIX. Essas duas localidades teriam conferido aos seus moradores uma identificação cultural específica; os da Cidade Alta eram denominados de "xarias", enquanto os da Ribeira de "canguleiros". Segundo Luís da Câmara Cascudo, ${ }^{22}$ essas denominações expressavam diferenças sociais importantes. Os xarias constituíam o grupo melhor aquinhoado, moradores da parte alta da cidade, centro do poder e da administração; receberam a alcunha pelo consumo de um peixe nobre, o xaréu. Os canguleiros, moradores de origem humilde, dedicados em grande parte à atividade portuária da região ribeirinha da cidade, ganharam essa denominação por serem comedores de cangulo, peixe de pouco valor comercial pescado na própria localidade. Tratavam-se de denominações cristalizadas ao longo do tempo, expressando a forte rivalidade entre os grupos, que se transformava em conflitos sociais. Ainda segundo Cascudo, essa rivalidade era expressa em diferentes momentos da vida social, tanto nas festas e diversões públicas (circo, Carnaval, Festa da Padroeira), quanto nos cortejos de sepultamento, ${ }^{23}$ e chegava ao confronto físico e verbal, a fim de garantir a demarcação dos territórios habitados. $\bigcirc$ grito de guerra entoado por ambos os grupos, "Xaria não desce! Canguleiro não sobe!", denotava o teor dessas fronteiras no interior da cidade.

Tais formas de identificação cultural foram profundamente alteradas nas primeiras décadas do século XX. Cascudo relacionou o fim dessa divisão às mudanças físicas na cidade, sobretudo àquelas advindas com a melhoria da via de ligação entre as duas localidades. Para o autor, o calçamento da ladeira da Avenida Junqueira Aires, principal corredor entre a Cidade Alta e a Ribeira, e a introdução do bonde teriam proporcionado o fim dessas identidades locais e o surgimento de uma identidade municipal. ${ }^{24}$

A criação de condições mais propícias para a circulação da população no território da cidade, entretanto, não pode ser tomada como fator preponderante no desenvolvimento de uma forma de identificação coletiva associada ao sentimento de pertencimento à cidade, como faz crer Cascudo. É importante compreender essas mudanças identitárias como relacionadas às transformações estruturais sociais e urbanas, e que a própria emergência de uma memória republicana no período não apenas coincide com tais mudanças, como serviu para dar sentido a elas.
21. Rubenilson Teixeira (2009) interpretou as mudanças na vida urbana do Rio Grande do Norte entre os séculos XVIII e XIX como marcadas por um profundo processo de secularização.

22. Cascudo (2010).

23. Ibid.

24. Ibid., p. 287-288. 
25. Cf. Ferreira (2009); Pinheiro (2005).

26. Tribuna Juvenil apud Ferreira, op. cit., p. 92
Desde as últimas décadas do século XIX, o desenvolvimento de uma economia urbana se estabeleceu a partir dos progressos alcançados com o impulso do comércio do algodão. A expansão do trabalho assalariado foi acompanhada pelo aparecimento, ou mesmo aumento, da força de trabalho urbana formada por comerciários, funcionários públicos, representantes comerciais, ferroviários, portuários, operários, profissionais liberais, entre outros. As rígidas fronteiras sociais que haviam marcado o mundo imperial abriam-se à mobilidade, fazendo da ascensão social uma possibilidade cada vez mais real. Mesmo estando essa ascensão muitas vezes pautada pela fidelidade política, o mérito profissional passava a ser gradativamente mais exigido. Desse modo, a educação se tornava um meio cada vez mais escolhido por aqueles que alvejavam galgar postos de trabalho mais altos.

Não foi por mera ideologia que a expansão da rede de ensino público se mostrou como uma das novidades associadas ao novo regime. ${ }^{25} \mathrm{~A}$ própria ideia de democracia e até de felicidade material e moral da nação, tão propagada pelos republicanos, só poderia ser alcançada quando fosse assegurada a instrução pública de ensino à população. A crença na função transformadora da instrução se apresentava como um novo diferencial ao caráter elitista que havia marcado a educação no período imperial. Para os republicanos mais radicais, a garantia da instrução pública à população era condição fundamental para assegurar a democracia e também a igualdade social. Já em 1890, um articulista do jornal Tribuna Juvenil expressava a questão da seguinte forma:

O nosso acrysolado amor a causa sublime das lettras, faz com que a nossa débil penna, não acostumada a discussão de graves questões, de leve toque n'um assumpto difficil, que constitue a questão vital das eleições e que deveria ser corollario immediato da revolução de 15 de novembro - a diffusão do ensino por todas as classes sociaes. Só assim tornar-se-ia realidade o sonho democrático dos povos, o nivelamento social. Hoje que o governo é do povo pelo povo, que seria dos destinos da pátria se os regesse alguém que da taça do saber não houvesse libado o divino ether?26

Por outro lado, a nova realidade urbana e social também provocou uma reconsideração do lugar social das mulheres na sociedade. A imagem da mulher do passado aparecia para os republicanos como profundamente limitada no aspecto educacional e isolada socialmente. Foi em tom de denúncia que um dos principais promotores do novo regime, o senador Eloy de Souza, a definia: "Era desprimor uma moça saber ler e escrever, bastando-the, como prendas para bem maridar-se, manejar algumas dúzias de bilros, conhecer a doutrina cristã, costurar 
roupas caseiras e ter dote" ${ }^{27}$ Os ideólogos republicanos instigavam as mulheres a desempenharem um papel cada vez mais ativo na vida pública e de relevância na sociedade moderna e urbana, mesmo que isso muitas vezes pudesse significar o realce de papéis sociais tradicionais.

As reformas urbanas estiveram relacionadas ao aumento da mobilidade de mercadorias e de pessoas. Os serviços de "melhoramento" do porto de Natal, intensificados durante a República, permitiram melhor escoamento da produção do estado, ao mesmo tempo que facilitavam a obtenção de mercadorias e valores importados, sobretudo de origem europeia. ${ }^{28}$ Havia também o desejo de tornar a cidade um espaço para desfrute. As obras de calçamento, iluminação pública, praças e jardins possibilitavam a exploração do espaço público como antes nunca visto. Além da construção de novas praças, como a Augusto Severo (1904) e a Sete de Setembro (1914), do ajardinamento da praça André de Albuquerque (1906) e da edificação do Teatro Carlos Gomes (1904), o período presenciou o calçamento de importantes ruas e avenidas, bem como a instalação dos bondes puxados a burros (1908) e do elétrico (19111). ${ }^{29}$ Todas essas ações ganharam sentido de "novidade" e, ao serem associadas ao novo regime, reforçavam ainda mais a sensação de que se estava vivendo uma nova época. ${ }^{30}$

Algumas dessas transformações foram induzidas e também capitaneadas pelo novo grupo político que assumiu o poder no estado com a instalação da República. Coube ao médico Pedro Velho de Albuquerque Maranhão ( 1856 -1907) estabelecer as bases do novo poder no estado. Foi ele o responsável pela instalação de uma oligarquia que governou o Rio Grande do Norte por mais de vinte anos. Além do próprio Pedro Velho, que foi presidente do estado (1892-1896) e depois senador da República (1903-1906), ocuparam a chefia do Executivo estadual Joaquim Ferreira Chaves (1 896-1900), seu irmão, Alberto Albuquerque Maranhão (1900-1904), seu genro, Augusto Tavares de Lyra (1 904-1906), Antônio de Souza (1906-1908) e novamente Alberto Maranhão (1908-1914).

A conquista do poder e a permanência dos Albuquerque Maranhão passou pelo estabelecimento de alianças políticas e sociais que envolviam uma rede de parentes e agregados. Essa rede política estava alicerçada não só no controle da máquina pública e da ocupação dos principais postos de representação política nas esferas municipal, estadual e federal, mas também na concessão de benesses a aliados e correligionários. Essas benesses passavam pela indicação a cargos públicos e pela facilitação na obtenção de terras públicas urbanas. ${ }^{31}$

Longe de governar dentro de um consenso social e político, a primeira oligarquia republicana foi atacada por uma oposição formada em grande medida por republicanos históricos que haviam sido excluídos do poder. Entre os principais
27. Souza (1999, p. 12).

28. Cf. Jobin (2015); Simonini (2010).

29. Cf. Andrade (2009); Marinho (2008); Oliveira (1999).

30. Cf. Mello (2007).

31. Cf. Siqueira (2014); Medeiros (2017). 
32. Sobre a implantação da República no Rio Grande do Norte e a consolidação da chefia de Pedro Velho, cf. Bueno (2002). Sobre as disputas políticas e simbólicas dos primeiros republicanos, cf. Airaghi (2016).

33. A análise aqui proposta procura romper com as abordagens institucionais, que reduzem a história da cidadania cívica à mera reconstituição das etapas legais que levam ao sufrágio universal, ou que a analisam levando em consideração apenas os comentários de textos jurídicos e de obras que a delimitam e tentam dar a ela um sentido.

34. Offerlé (2005).

35. Ibid., p. 346. opositores estavam Elias Souto e seu jornal, o Diário de Natal, que durante anos se apresentou como uma voz de denúncia dos abusos e arbitrariedades cometidas pelos novos governantes. No entanto, apesar dessa oposição ruidosa, o período de governo dos Albuquerque Maranhão conseguiu instaurar um clima de relativa estabilidade, mesmo que para isso tenha feito uso da censura e da perseguição a opositores. $^{32}$

Neste trabalho procurei entender o sentido da identidade natalense, nas primeiras décadas do século XX, como algo vinculado ao desenvolvimento da cidadania cívica e ao processo de cidadanização nacional. ${ }^{33}$ Muito mais do que o sentimento de pertencer ao local onde nasceu, o natalense foi sendo definido pela comunhão e pela participação em uma série de práticas cívicas vivenciadas na capital, mas que também eram intercambiáveis com experiências similares em todo o país. Analisando especificamente o processo de cidadanização cívica na França, o cientista político Michel Offerléz ${ }^{4}$ chegou à conclusão de que ele estaria ligado à própria construção da identidade nacional. Para o autor, aquele movimento pelo direito do voto deveria ser entendido como uma ação que caminhava em "paralelo ao estabelecimento de outras formas de cidadania pelo desenvolvimento da obrigação de ser francês, do interesse e do sentimento de sê-lo". 35

$\bigcirc$ entendimento desse processo de identificação cultural passa pela compreensão das instituições públicas e de sua atuação no meio social, pois foram elas as principais responsáveis pela conformação desses espaços. Entre as instituições mais importantes neste estudo está o Instituto Histórico e Geográfico do Rio Grande do Norte (IHGRN), fundado em 1902. Esta entidade reuniu um grupo de intelectuais que tinham relação orgânica com o novo regime republicano e com a chefia de Pedro Velho. Assim como instituições similares em outros estados do país, o IHGRN esteve voltado para a pesquisa da história e da geografia do próprio estado.

Nas duas primeiras décadas de existência, o instituto era composto por membros oriundos predominantemente das elites agrária e comercial do Rio Grande do Norte. No entanto, alguns desses membros pareciam vir de grupos sociais mais humildes ou de famílias em declínio econômico, como os professores Francisco lvo Cavalcanti e Antônio Gomes da Rocha Fagundes. O primeiro trabalhou inicialmente como estafeta dos Correios e depois de formar-se como professor primário abriu uma escola na própria casa, ministrando aulas de diversas matérias. $\bigcirc$ segundo foi alfaiate e cursou a Escola Normal, onde posteriormente foi professor.

A formação intelectual dos membros-fundadores era predominantemente bacharelesca. Dos 27 integrantes que criaram a instituição, vinte tinham formação superior, sendo dezenove em direito e um em medicina. Muitos desses membros 
desempenharam um papel importante no poder Judiciário do estado, a exemplo de: Vicente de Lemos, primeiro presidente do IHGRN, que chegou ao cargo de desembargador do Tribunal de Justiça do Estado; Augusto Tavares de Lyra, que assumiu o cargo de presidente do Tribunal de Contas da União; Antônio Soares de Araújo, que foi desembargador e presidente do Tribunal Regional Eleitoral; José Teotônio Freire, que exerceu os cargos de promotor público em Mossoró (1 886), Açu (1 887) e Nova Cruz (1 888) e foi juiz municipal em Capão Bonito do Paranapanema (SP) (1 889), Pau dos Ferros (1890) e Macaíba (1892). Em 1898, este último tornou-se desembargador, e de 1909 a 1921 foi presidente do Superior Tribunal de Justiça.

Outros exerceram cargos políticos, como Pedro Velho, que foi eleito deputado federal em 1890 e dois anos depois assumiu a presidência do estado, posteriormente exercendo o cargo de senador da República (1 896-1906); Augusto Tavares de Lyra, que foi deputado no Congresso Legislativo (1894-1904), presidente do estado (1903-1906), ministro da Justiça e Negócios Interiores do governo de Afonso Pena, além de senador e ministro da Viação e Obras Públicas do governo de Venceslau Brás; e Eloy de Souza, que foi deputado na Assembleia Legislativa (1895-1897), eleito diversas vezes deputado federal, chegando por fim a ser senador em 1914.

Um grupo menor de membros do IHGRN tinha formação em magistério, como os já citados professores Antônio Fagundes e Francisco Ivo. No entanto, a atuação no magistério contou com um número significativo de membros do instituto. Nestor dos Santos Lima foi professor da Escola Normal, assim como Antônio Fagundes e Francisco Ivo. Antes de clinicar, Pedro Velho ensinou história no Atheneu Norte-Riograndense, o mesmo acontecendo com o advogado Augusto Tavares de Lyra e posteriormente com o bacharel Luís da Câmara Cascudo.

As origens da instituição estiveram em grande parte ligadas às demandas políticas e simbólicas emergentes com a implantação da República no país, sendo a principal delas a reorganização das esferas de poderes e dos territórios da federação. No Rio Grande do Norte foram as disputas em torno dos limites entre os novos estados que mobilizaram os intelectuais no estudo da história territorial. A chamada "Questão de Grossos", disputa territorial entre o Rio Grande do Norte e o Ceará, esteve na origem da instituição. ${ }^{36}$ Conforme assinalou Saul Estevam Fernandes:

Embora não faça referência em sua Ata de Criação, a fundação do IHG-RN estava diretamente relacionada à questão de limites. Sobretudo, pela necessidade do árbitro Coelho Rodrigues em apresentar provas no Tribunal Arbitral. Não por acaso, o Instituto foi criado no mesmo dia da assinatura do acordo que iniciou a nova fase de conflito. ${ }^{37}$
36. Cf. Fernandes (2016); Viana (2009).

37. Fernandes, op. cit., p. 94. 
38. Essas experiências se enquadram naquilo que Michael Pollak (1992, p. 202) denominou de "acontecimentos vividos por tabela".

39. Segalen (2002, p. 32).
Nesse sentido, coube aos membros do IHGRN participar da produção de uma historiografia que definisse o estado e sua capital como unidades importantes de identidade social que, mesmo se mostrando parte constitutiva do nacional, guardavam suas especificidades. A importância depositada nessa instituição denotava o papel que o conhecimento histórico, enquanto saber laico, racional, mas também afetivo, deveria assumir na organização da vida pública da cidade. Outro aspecto, não menos importante, que mobilizou a atuação da instituição foi a busca pelas raízes do republicanismo no estado. Para isso, alguns de seus membros se voltaram para a pesquisa em torno de personagens e fatos históricos que fossem dignos de nota. Por meio da difusão de biografias e relatos de acontecimentos históricos, os membros do instituto procuravam compartilhar uma memória que os cidadãos não viveram. ${ }^{38}$

Porém, conforme veremos neste estudo, além da atuação no campo historiográfico, os membros do instituto tiveram papel fundamental na redefinição do mundo material e na reorganização do espaço público urbano como estratégias importantes de construção de uma identidade natalense. Assim, edificando monumentos, elencando acontecimentos, lugares e personagens dignos de valor histórico ou organizando as principais cerimônias de caráter cívico republicano, o IHGRN apresenta-se como instituição central desse processo.

Este estudo é uma tentativa de compreender a construção dos monumentos e dos rituais realizados ao redor do instituto na cidade de Natal entre 1902 e 1922, como processo profundo de mudança de sentido do espaço urbano. Nesse aspecto, a noção de ritos ou rituais pode ser entendida

\begin{abstract}
enquanto conjuntos fortemente institucionalizados ou efervescentes - quer regulem situações de adesão comum a valores, quer funcionem como reguladores de conflitos interpessoais -, os ritos devem ser considerados sempre como um conjunto de condutas individuais e coletivas relativamente codificadas, com suporte corporal (verbal, gestual e de postura), caráter repetitivo e forte carga simbólica para atores e testemunhas. ${ }^{39}$
\end{abstract}

Para analisar essas experiências, procurou-se identificar os principais agentes que erigiram tais monumentos e que também motivaram a celebração e produção de uma história voltada para dar sentido a esses objetos públicos. Examinando a ação dos republicanos norte-rio-grandenses, fica clara a importância da produção historiográfica, da celebração cívica e da construção de monumentos na organização e na produção do sentido de espaço público como espaço cívico. Agindo com este intuito, essas elites procuraram conferir ao território da cidade um 
importante papel na vida política urbana, ao definirem um script para os cidadãos celebrarem e ritualizarem a "memória republicana".

Os estudos sobre a memória republicana ganharam grande dimensão com - trabalho de José Murilo de Carvalho ${ }^{40}$ sobre a produção da simbologia republicana, seus agentes, genealogias e ideologias. $\bigcirc$ autor examinou uma série de dispositivos produzidos pelos republicanos para legitimar o novo regime, tais como três dos principais monumentos edificados em praça pública no Rio de Janeiro e em Porto Alegre, a idealização de Tiradentes como herói republicano nacional, passando pela concepção da bandeira e do hino nacional. Um dos aspectos demonstrados por Carvalho foi que, diferente da francesa, a conquista da legitimidade republicana brasileira foi estabelecida a partir da associação da nova simbologia com os antigos referenciais cristãos e do regime monárquico. Entre os estudos voltados para a produção simbólica dos monumentos destacam-se os trabalhos de Coelho, ${ }^{41}$ Doberstein ${ }^{42}$ e Uhle. ${ }^{43} \bigcirc$ estudo de Doberstein versa sobre os elementos ideológicos presentes na estatuária positivista portalegrense e analisa o conjunto dessa produção local entre 1900 e 1920, considerando os diversos grupos sociais (governo republicano positivista e elites burguesas) que as encomendaram, os elementos estéticos que as definiram e seu caráter industrioso. $\bigcirc$ autor, mesmo tomando a especificidade de cada obra escultórica, procura compreender o conjunto dessa produção por aquilo que denominou de "historicismo multi-industriado transalegórico", ou seja, dentro de um domínio em que as obras foram tomadas como recuperação dos estilos passados, mas ao mesmo tempo incorporaram os referenciais materiais, técnicos e de produção do mundo industrial da transição do século XIX para o XX. Esse processo teria sido responsável por dar a alegoria uma "de compreensão objetiva, quase elementar", capaz de "desestimula a fantasia, a imaginação e a emoção", promovendo assim um deslocamento no sentido das obras até readquirir um caráter de símbolo. Essa dimensão simbólica seria, para o autor, não "resultado das reações psíquicas e inconscientes do espectador, mas da ideologia de seus patrocinadores e/ou produtores". 44

Já o estudo de Coelho foca a experiência pioneira belenense na inauguração do primeiro grande monumento de celebração da República no país, no dia 15 de novembro de 1897, na Praça da República. Coelho examina o processo de concepção, produção e inauguração do Monumento à República, de autoria do escultor genovês Michele Sansebastiano, e todo o imaginário que permeou essa experiência. Assim como José Murilo de Carvalho, que associa a produção francesa do imaginário republicano à brasileira, Coelho explora algumas dimensões novas, como as diferentes imagens de Marianne nos dois contextos nacionais. Enquanto na França da Terceira República a imagem de Marianne se apresentava cada vez
40. Carvalho (1990).

41. Coelho (2002).

42. Doberstein (2002).

43. Uhle (2015).

44. Doberstein, op. cit., p. 110 e 115. 
45. Coelho, op. cit.

46. Uhle, op. cit.

47. Knauss (2003)

48. Abreu (2003).

49. Gonçalves (2000).

50. Marcelino (2016)

51. Gonçalves, op. cit. mais despolitizada, a fim de sepultar qualquer referência aos communards, em Belém, onde imperava a retórica radical do florianismo local, a imagem da Marianne assumiu conotação mais politizada, sendo retratada vestida com o barrete frígio e um gládio em punho. ${ }^{45}$

$\bigcirc$ artigo de Uhle ${ }^{46}$ analisa 0 processo de avaliação das propostas apresentadas para a edificação do primeiro monumento concebido na República em homenagem a São Paulo. A fim de compreender a proposta vencedora, do artista Amadeu Zani, a autora reconstrói as negociações que envolveram a própria Comissão Executiva do concurso e o grupo de escultores participantes, assinalando os conflitos subjacentes de concepções simbólicas e narrativas na avaliação das obras.

Outros trabalhos são também merecedores de destaque, como os de Knauss ${ }^{47}$ e de Abreu, ${ }^{48}$ ambos versando sobre a experiência da estatuária republicana na cidade de Niterói nas primeiras décadas do século XX.

Também houve estudos voltados para o papel das cerimônias cívicas na produção de memória republicana. A partir de uma abordagem antropológica, alguns trabalhos ofereceram uma compreensão não só da dimensão ideológica, mas também ritualística dessas práticas. Gonçalves ${ }^{49}$ e Marcelino ${ }^{50}$ se debruçaram sobre o papel dos funerais cívicos como importantes ritos de produção dessa memória. Gonçalves, ao analisar o funeral de Rui Barbosa, procura demonstrar como esse ritual foi capaz de imortalizar uma figura pública, transformando um indivíduo em herói nacional. Assim, o funeral público é tomado como rito de incorporação, no qual o nome de Rui Barbosa é vinculado ao "templo dos imortais brasileiros". Nesse ritual, diferentes elementos contribuem para tal incorporação, desde a escolha do local do velório la Biblioteca Nacional), passando pelos discursos proferidos, pelo cortejo até o enterro propriamente dito. Segundo Gonçalves, no contexto da Primeira República carioca o funeral cívico como rito solene e afirmador de hierarquia correu o risco de perder sua eficácia simbólica, uma vez que a forte carnavalização popular, expressa por meio de caricaturas, piadas, canções carnavalescas, filmes e depoimentos, era capaz de subverter a ordem das celebrações. ${ }^{51}$ Já Marcelino concentrou os estudos dos rituais fúnebres naqueles destinados aos "homens de letras". Para ele, a grande dimensão tomada por esses rituais no início do século XX no país assinalou uma mudança simbólica importante estabelecida pelo regime republicano. Tal dimensão estava marcada pela valorização da figura do intelectual das letras e sua autonomia em relação às contingências do mundo político. Ao analisar cerimônias e discursos funerários de três grandes escritores nacionais Machado de Assis, Arthur 
Azevedo e Euclides da Cunha), Marcelino interpreta que a forma assumida por essas práticas assinala uma crescente consolidação dos valores republicanos. Para ele, essa experiência cívica "parece indicativa de alterações mais profundas não apenas nos mecanismos de ritualização do poder, mas nas formas de lidar com a temporalidade dentro de um regime ritual". 52 Assim, o autor procura inscrever o sentido dado aos funerais de "homens de letras na passagem do Império para a República" ao lado de outras alterações relevantes, como as verificadas nas formas de escrita do passado nacional, nas mudanças no regime de memória e nas práticas cívicas.

As práticas de simbolização e ritualização do poder não foram exclusivas do regime republicano, ao contrário, estiveram presentes também no período imperial como forma de legitimar o poder do monarca. Sobre as simbologias e cerimônias do poder monárquico no país. ${ }^{53}$

Outros estudos procuraram evidenciar que, mais do que um consenso político, as celebrações cívicas refletiam tensões sociais importantes que marcaram o início da implantação da República no país. Albuquerque, ${ }^{54}$ por exemplo, mostrou como, na Bahia pós-Proclamação da República, o sentido dado às celebrações do Dois de Julho organizadas pelas elites locais republicanas buscou estabelecer também o controle e a seleção cultural sobre as condutas dos participantes, entrando assim em conflito com os usos populares dessas celebrações. No caso baiano, os conflitos assumiram significativa dimensão étnico-racial, que pode ser vista nas ações das elites republicanas em se opor a qualquer simbologia e comportamento de referência africana.

Assim como Albuquerque, que tomou os rituais cívicos como marcados por tensões sociais, os trabalhos de Kraay ${ }^{55}$ estiveram voltados para um contexto anterior, pós-Independência, em Salvador e no Rio de Janeiro. Kraay procurou ampliar o escopo dessas tensões a fim de incluir também as existentes no interior das elites provinciais (entre indivíduos que buscavam maior autonomia e os que queriam manter o atrelamento ao poder central), entre a elite e os populares, mas também entre os próprios populares. Sobre estes últimos, o autor destaca que, ao mesmo tempo que havia uma provável popularidade da iconografia monárquica (utilizada como instrumento de patriotismo) entre os baianos de diferentes classes sociais, os populares concebiam as comemorações do Dois de Julho como uma conquista sua e não como benesse de Dom Pedro I. Nesse aspecto o autor defende a ideia de que "não se deve justapor de forma ingênua interpretações populares e elitistas da independência ou impor-thes uma unidade que inexistia". 56
52. Marcelino, op. cit., p. 277.

53. Cf. Ribeiro (1995).

54. Albuquerque (1999).

55. Kraay (2001, 2008).

56. Kraay (2001, p. 83) 
Foi na cidade de Natal, capital do Rio Grande do Norte, que a produção historiográfica e o trabalho de memória assumiram proporções sociais significativas, ao serem ritualizados através de manifestações cívicas e celebrações públicas. discurso e a atuação do $\Vdash H G R N$ na construção da memória republicana reservaram ao universo material um lugar central. Assim, para que a população pudesse se lembrar do dia Quinze de Novembro, data da Proclamação da República, além de promover o contato com as narrativas historiográficas ou com discursos públicos, foram erguidos monumentos, marcadores físicos, visíveis e palpáveis a qualquer transeunte da cidade.

Esse processo não deixava de promover uma forma de reificação social, não só por que estabelecia uma associação artificial entre as ideias dos republicanos e os objetos, mas também por que, ao fazê-lo, permitia perenizar tais ideias, tornando-as independentes das relações sociais que as originaram.

Quando as idéias, enquanto produtos da mente (artefatos mentais), são transformadas em objetos materiais "exteriores", revestem-se de um caráter de permanência relativa. Dotadas dessa forma material permanente, as idéias podem tonar-se objetos de operações técnicas que ultrapassam a capacidade da mente em agir por si própria. ${ }^{57}$

Com os republicanos, a cidade tornou-se o espaço privilegiado da memória, passando a ser identificada pela própria toponímia urbana e pelas edificações. Para isto, foi realizado um vasto trabalho de nomeação e renomeação de ruas, praças e logradouros.

Já em 1906, o IHGRN promoveu uma grande cerimônia em homenagem aos 89 anos da morte de Frei Miguelinho, líder rebelde que havia participado do movimento insurrecional de 1817. Após a solenidade, os membros do instituto requisitaram da Intendência da cidade a mudança do nome da rua Treze de Maio, no bairro da Ribeira, para rua Frei Miguelinho, no que foram prontamente atendidos.

Mudanças ocorridas posteriormente na toponímia urbana atestariam também esse novo sentido da memória. As avenidas abertas duas décadas depois, nos dois novos bairros da cidade, tiveram seus nomes ligados a referências do republicanismo nacional. De Deodoro da Fonseca a Hermes da Fonseca, os bairros de Petrópolis e Tirol ganhariam longitudinalmente as denominações de sete presidentes da Primeira República, enquanto latitudinalmente a homenagem seria dada aos principais rios encontrados no estado. 
As alterações na toponímia não deixaram de ser vistas como estratégia política de legitimação dos Albuquerque Maranhão no poder. Em 1909, o jornal oposicionista Diário de Natal denunciou os usos políticos subjacentes a tais práticas.
Na nova ordem das cousas, os destinos das terras da oligarquia estão sob a influência dos seus pro-homens, em tudo por tudo, perdendo já vão os seus primitivos nomes. Consequencia fatal, se não me engano, da febre engrossativa que lavra nos domínios do partido dominante. Ruas, villas, cidades, municípios estão sendo rebaptizados, como se estivessem entrando numa nova seita. Os nomes dos antigos estão sendo (nas ruas) substituídos pelos modernos estadistas - Pedro Velho, Augusto Lyra - Alberto Maranhão, Fabrício Maranhão. O processo de rebaptizamento é simples: faz o chefe político do local a proposta e esta enthusiasticamente é aceita pelo conselho. Nada mais, está feita a operação [...].58

Apesar das críticas, essas práticas de nomeação e renomeação tornaram-se cada vez mais presentes no ambiente urbano. Além das ruas e avenidas, uma série de edifícios públicos construídos no período recebeu nomes de figuras importantes das oligarquias e do republicanismo local. Os primeiros grupos escolares da capital ganharam os nomes de Augusto Severo, Frei Miguelinho, Quintino Bocaiúva e Fabrício Maranhão. $\bigcirc$ primeiro, além de irmão de Pedro Velho e deputado federal durante a década de 1890, era inventor e veio a falecer precocemente no ano de 1902, ao realizar um voo teste com seu dirigível Pax. Outro homenageado, Fabrício Maranhão, era também irmão de Pedro Velho, além de empresário e chefe político do município de Canguaretama, situado a cerca de 80 quilômetros ao sul da capital. As três principais praças da cidade construídas no período receberam os nomes de André de Albuquerque llíder do movimento insurrecional de 1817 da antiga província e sentenciado à morte por representantes da Coroa Portuguesa), bem como, novamente, de Augusto Severo e Pedro Velho. Em 1905, depois de um longo período de aterramento, drenagem e ajardinamento da Ribeira, a Intendência Municipal inaugurou o principal logradouro do bairro, a praça Augusto Severo. Tratava-se de mais uma vez homenagear o inventor e político, figura central do clã Albuquerque Maranhão.

Além da nomeação de ruas e logradouros, outra ação importante na construção dessa "memória republicana" no território da cidade foi a edificação de monumentos. A maior parte deles era feita de pedra ou bronze, o que aumentava sua resistência ao tempo, tornando-os capazes de se perpetuar por várias gerações. Muitos estudiosos acreditavam no caráter pedagógico e duradouro dos monumentos, ao permitirem que gerações futuras compartilhassem os mesmos sentimentos daquelas que os instituíram. 
59. Souza (2008b, p. 151).

60. Décadas mais tarde o monumento foi transferido, em caráter definitivo, para uma imensa praça arborizada com o mesmo nome, situada no recémcriado bairro de Petrópolis.

61. Ibid., p. 292-293.
Já nos primeiros anos da República seriam erguidos vários desses monumentos nas diversas praças ou em algumas das principais avenidas da cidade. Assim, logo após a morte de Pedro Velho, em dezembro de 1907, os membros do IHGRN mandaram esculpir um monumento em sua homenagem. $O$ projeto foi encomendado ao escultor Corbiniano da Silva Vilaça, que por sua vez recorreu aos serviços de um colega francês, Edmond Badoche, o mesmo que havia feito uma obra semelhante para exaltar o escritor Júlio Verne na França. ${ }^{59} \mathrm{O}$ monumento consiste em um busto de Pedro Velho, modelado em bronze e fixado sobre um pedestal de granito, tendo à frente uma figura feminina que oferece um ramo votivo representando a pátria norterio-grandense. A obra seria inaugurada em 1909, num espaço provisório denominado Square Pedro Velho, localizado na Cidade Alta. .0

Anos mais tarde, um monumento em forma de obelisco foi fixado próximo ao Cais Tavares de Lira, no bairro da Ribeira. Talhado em Paris e inaugurado em 1913, durante o segundo governo de Alberto Maranhão (1908-1914), o monumento tinha como função exaltar o nome do ex-governador do estado e uma das lideranças do republicanismo potiguar, Augusto Tavares de Lyra. Nele havia uma efígie em bronze do homenageado, e abaixo dela a inscrição "Avenida Tavares de Lira, administração do Governo Alberto Maranhão, 1908-1914". . $^{61}$ No monumento estavam gravadas, sobre a pedra dura, as legendas com as efemérides que os cidadãos natalenses jamais deveriam esquecer: 25 de dezembro de 1599, data da fundação da cidade de Natal; 12 de dezembro de 1633, data da retomada pelos portugueses do Forte dos Reis Magos, antes sob domínio holandês; 7 de setembro de 1822, data da Independência do Brasil; e 15 de novembro de 1889, data da Proclamação da República no país. As efemérides chamavam atenção para os marcos históricos de fundação da cidade - o momento em que teve sua autonomia restaurada, sua ligação com as lutas mais gerais de independência nacional e de estabelecimento do regime republicano no país. A referência à presença holandesa na capitania do Rio Grande do Norte, por exemplo, atestava a preocupação dos republicanos com a necessidade de vigilância constante sobre as conquistas alcançadas, sob pena de que algum invasor viesse usurpá-las.

Outro obelisco foi edificado na recém-reformada praça André de Albuquerque, em meio aos passeios e jardins. O Monumento aos Mártires de 1817, como foi denominado, era uma construção que procurava fazer lembrar, a partir do nome do herói André de Albuquerque, todos os pioneiros da luta republicana no território potiguar. Na coluna de granito de quatro faces foram gravadas, em medalhão de bronze de $88 \times 65$ centímetros, inscrições em latim em reverência aos heróis de 1817, bem como o escudo do estado e as bandeiras do 
movimento e da República. Numa das faces da coluna estava inscrita a data de 17 de dezembro de 1597, quando aportou na região, ainda dominada por franceses, a expedição portuguesa que ocupou a área definitivamente. As referências às duas datas procuravam estabelecer um elo entre os dois momentos históricos da cidade e do estado, identificando o regime republicano como legítimo continuador da história estadual.

As homenagens, no entanto, não ficaram restritas aos elementos da política local, mas se estenderam a outros segmentos sociais. Em 7 de agosto de 1919, os membros do IHGRN procuraram prestar tributo ao padre João Maria, pelo $38^{\circ}$ aniversário de sua vigairaria na paróquia de Natal. Para isto, foi proposto inaugurar uma praça com seu nome e fixar uma herma como "sinal de pública homenagem à venerável memória do sacerdote cristão".62

Apesar de figurar durante o Império uma política de homenagens aos chamados "grandes homens", pautada por moldes iluministas, essa política ainda estava marcada pela centralidade da figura imperial e das práticas e formas de sociabilidade aristocráticas. Apenas no final do Império ocorreu um deslocamento da centralidade da figura do monarca, enquanto a consagração cívica passava a ser cada vez mais amparada pela evocação das ruas. ${ }^{63}$ Os ideais republicanos, antes de privilegiarem o nascimento e a origem social, procuravam evocar novos valores, como o mérito e supostas virtudes cívicas. Nesse contexto foi adicionado um conjunto de novos personagens, composto por figuras destacadas do mundo das letras e da ciência. Assim, conforme assinalou Douglas Attila Marcelino:

As formas de glorificação recém-inauguradas seriam pródigas na exaltação desse novo tipo de personagem, cada vez mais aproximado do "homem comum", que, movido por ideais humanitários, não proviria apenas dos estreitos quadros do mundo nobiliárquico, figurando por suas próprias qualidades cívicas em uma verdadeira "república de talentos". ${ }^{64}$

Foi deste modo que a poetisa Auta de Souza, falecida em 1901, aos 25 anos de idade, foi homenageada com uma praça e um monumento em seu nome. Auta de Souza era membro de uma das famílias mais influentes do novo regime, os Castriciano. Seus dois irmãos, Eloi e Henrique Castriciano, foram figuras destacadas na política e na vida intelectual local. No entanto, o que chama atenção na evocação do nome de Auta de Souza não era tanto sua filiação, mas o fato de ser ela uma mulher, escritora e negra.

A importância dada às letras no novo regime resultou também numa homenagem póstuma à escritora Nísia Floresta. Durante os festejos do Centenário
62. Revista do Instituto Histórico e Geográfico do Rio Grande do Norte (1919b, p. 176).

63. Cf. Mello (2007).

64. Marcelino, op. cit., p. 263. 
65. Não se tratava da primeira homenagem a escritora. No ano de 1909, o Congresso Literário e um grupo alunos do Atheneu Norte-Riograndense, com apoio do governador Alberto Maranhão, ergueram um monumento em Papari, cidade natal da escritora, para homenageá-la. $\mathrm{Na}$ época, os participantes do evento achavam, erroneamente, que estavam comemorando o centenário de nascimento da escritora, que só ocorreria um ano depois. da Independência do país, foi instalada uma efígie de bronze cravada sobre uma coluna de granito na praça Augusto Severo no bairro da Ribeira (Figura 1). A escritora, que durante muito tempo havia sido persona non grata nos ambientes sociais natalenses devido ao seu comportamento fora dos padrões convencionais e pelos seus escritos em prol dos direitos femininos, teve seu nome imortalizado em praça pública por meio desse monumento. ${ }^{65}$

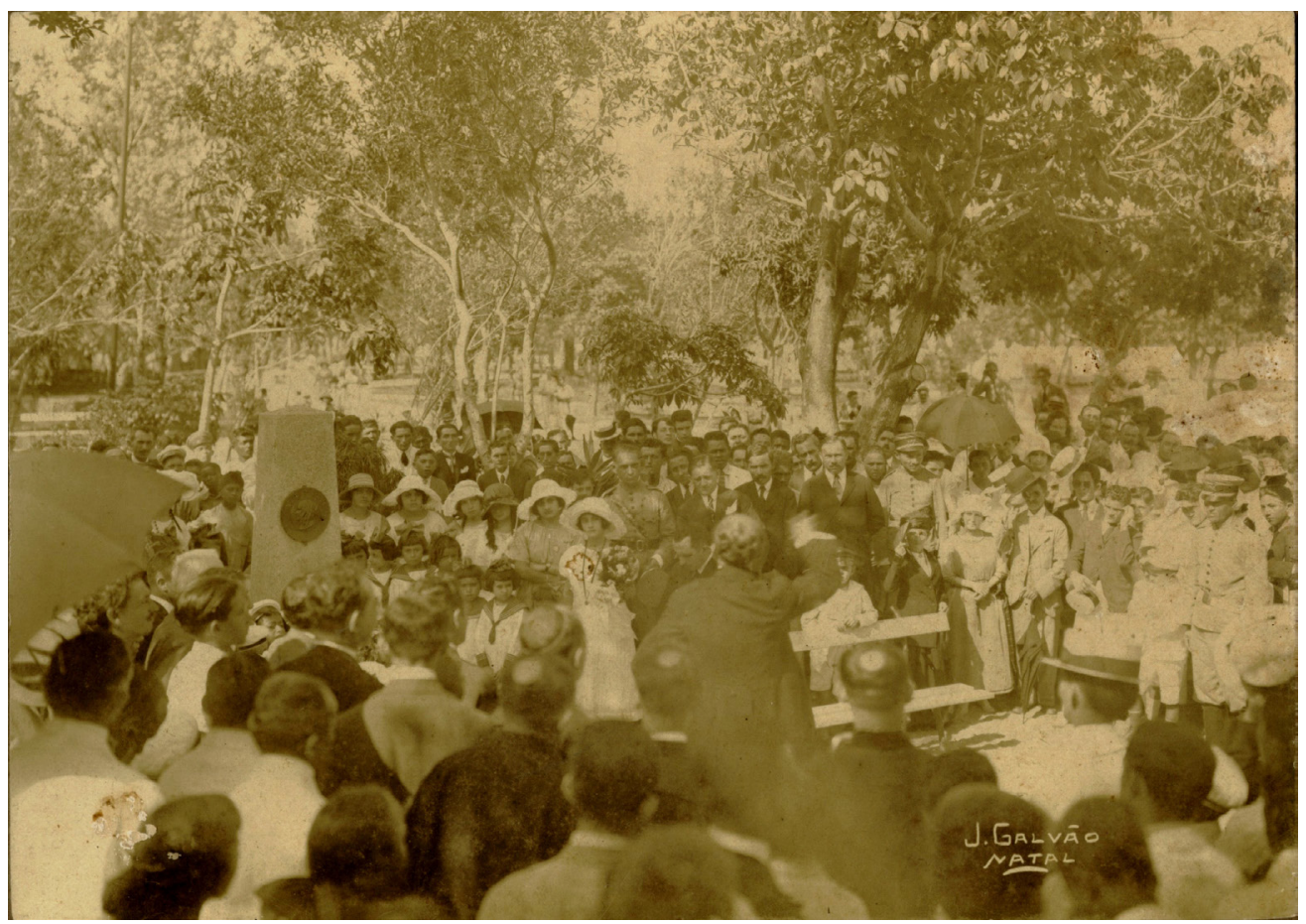

Figura 1 - Cerimônia de homenagem aos literatos potiguares em frente à herma da poetisa Nísia Floresta É possível ver a importância da presença feminina na cerimônia cívica em razão do lugar que ocupam as moças: em frente ao orador. Estas cerimônias constituíam um espaço estratégico de visibilidade pública feminina, ao mesmo tempo que a presença das mulheres dava um sentido de familiaridade. Fonte: Acervo Fotográfico do IHGRN (1922). Foto: J. Galvão.

As homenagens feitas às duas escritoras coincidiam com um período de grande efervescência da presença feminina na vida pública e intelectual. Nos anos de 1914 e 1915, por exemplo, as escritoras Palmira e Carolina Wanderley publicaram a revista Via-Láctea, primeiro periódico no estado criado e editado por mulheres. A revista serviu para tornar pública uma produção literária feminina local, mas também para emitir opiniões e reflexões sobre temas como arte, moda, educação, feminismo, política, entre outros. Ainda em 1914 era inaugurada a primeira escola dedicada ao ensino 
feminino no estado. A Escola Doméstica havia sido idealizada pelo pedagogo Henrique Castriciano e tinha como base o modelo de ensino para moças adotado na Suíça. ${ }^{60}$

A criação de monumentos não se limitou à política da estatuária e de blocos de pedra, mas agrupava outros tipos de suporte material que poderiam habitar nos espaços internos dos prédios públicos. Nesse aspecto, os quadros também foram utilizados, sobretudo porque poderiam ampliar o trabalho de memória. Ao serem disponibilizados em lugares fechados, eles possibilitavam ao observador uma relação mais pessoal e até introspectiva com a atividade mnemônica.

Muitos desses quadros eram compostos por retratos de líderes políticos locais, mas outros representavam acontecimentos históricos, conforme a tradição das pinturas históricas desde o Império. A introdução desses quadros ampliava as formas de representação do passado, já que os objetos escultóricos utilizados na cidade consistiam basicamente em bustos, hermas, estátuas e obeliscos em monobloco. Embora estes fornecessem uma imagem de personagens ou a referência temporal dos acontecimentos históricos dignos de nota, eram pobres em imagens que pudessem permitir uma narrativa dos eventos e personagens.

Um desses quadros foi $O$ julgamento de Frei Miguelinho. Encomendado pelo governador do estado, Joaquim Ferreira Chaves, no ano de 1917, o quadro deveria compor as comemorações marcadas para o centenário de morte do frei rebelde. A peça foi encomendada ao pintor carioca Antônio Parreiras e deveria retratar o momento em que o sacerdote, envolvido na insurreição de 1817, apresentava-se ao Tribunal Militar da Bahia para receber sua sentença de morte. A tela deveria ser colocada no salão principal do Palácio do Governo, a fim de que todo cidadão que adentrasse o recinto pudesse "testemunhar" esse personagem histórico que havia fincado as raízes do sentimento republicano no Rio Grande do Norte. ${ }^{67}$

A presença do IHGRN foi notória em todo o processo de concepção e realização do quadro. Através de uma comissão especial formada para fiscalizar o trabalho do artista, a instituição exerceu forte controle sobre sua execução, emitindo pareceres a respeito dos esboços apresentados e solicitando correções naquilo que não guardava fidelidade com o "fato histórico" retratado. ${ }^{68}$ No relatório final apresentado pelos membros da comissão à Direção do instituto para avaliar o resultado do trabalho de Parreiras, ficava expresso o caráter de monumentalidade que o objeto deveria possuir, a fim de associar a importância do evento representado com a história do republicanismo norte-rio-grandense:
66. Ferreira (2009); Pinheiro (2005).

67. Paiva (2011).

68. O controle do Instituto sobre os monumentos construídos pode também ser evidenciado no processo de produção do monumento do Centenário de Independência do Brasil. A obra ficou a cargo do escultor A. Bibiano Silva, residente no Recife, mas submetido ao crivo ideológico do IHGRN, que solicitava periodicamente do escultor o envio de "fotografias de frente e de perfil do monumento, antes da fundição, a fim de que o Instituto pudesse propor pequenas modificações que por ventura fossem desejadas" (Revista do Instituto Histórico $e$ Geográfico do Rio Grande do Norte, 1922, p. 20). 
69. Revista do Instituto

Histórico e Geográfico do Rio Grande do Norte (1919a, p. 157-158).

70. Ibid., p. 172 .

71. Bittencourt (1986); Meneses (1992).
A grandiosa tela fixou perpetuamente aquele edificante episódio histórico, dando-the o verdadeiro cunho de majestade que os cronistas nos deixam entrever nos relatos que fazem da malograda revolução nativista de 1817.

Ali, nas grandes linhas do imponente quadro ficará eternizado o gesto inimitável e nunca assaz aplaudido com que o nosso imortal compatriota repeliu a insinuação, porventura pérfida, do presidente da comissão militar, que lhe acenava com a falsidade da assinatura do acusado nos documentos apreendidos. ${ }^{69}$

$\bigcirc$ quadro também procurava eternizar aquilo que o tempo poderia levar ao esquecimento. $\bigcirc$ principal papel desempenhado pelo instituto era atestar se a tela era fiel à "verdade histórica", ou seja, se aquilo retratado corresponderia às crônicas da época e aos testemunhos inquestionáveis.

A delineação do quadro obedece à verdade histórica, podendo ver-se dos traços esboçados, que a figura de Miguelinho exprimirá "a doçura evangélica de sua fisionomia, onde transluzia a calma tranqüila da sua consciência" que, no dizer de um cronista da época, tanto espantou os juízes que julgaram o herói norte-riograndense. ${ }^{70}$

Diferentemente da ideia que os membros do IHGRN queriam passar, a cena retratada estava fortemente marcada pela idealização e pela mitificação de Frei Miguelinho. Assim, o quadro não captava "aquilo que de fato aconteceu", mas uma série de sentimentos emblemáticos, como a calma diante da extrema adversidade, a plena convicção do herói sobre o ato praticado e a manifestação de respeito de seus algozes lque subliminarmente traz um sentimento de culpa), os quais constituem um conjunto de significações ideais para a mitificação do herói e para uma longa existência do mito.

A representação pictográfica ajudava a estabelecer uma imagem dos episódios e personagens que deveriam ser eternizados. Cada vez mais se tornava comum o uso de suportes imagéticos para estabelecer as memórias do passado. ${ }^{71}$

Nesse processo de construção da memória republicana na cidade de Natal, uma experiência assinala o surgimento de um novo sentido: a construção da praça Sete de Setembro e do Monumento da Independência para os festejos do Centenário da Independência do país. A praça e seu monumento, construídos em frente ao Palácio do Governo, assinalam o compromisso da elite dirigente local com o regime federativo, afastando definitivamente as tendências confederadas e separatistas. Por outro lado, constituem um mecanismo que 
procura inscrever a população local nos quadros de uma solidariedade cívica nacional, conforme propagava uma autoridade durante os festejos do Centenário da Independência:

Que este modesto monumento seja para nós, não somente a homenagem à glória da pátria e à memória daqueles que no-la deram, mas o marco inicial e um novo caminho, a inauguração de uma nova era de esforço, de trabalho e de patriotismo. ${ }^{72}$

Fincado sobre um pedestal de granito no centro da praça, o monumento tinha como eixo duas figuras simbólicas: uma feminina, representando a Pátria; a outra masculina, representando o Povo. A Pátria, apontando para o Livro da História apoiado sobre um bloco de granito, indica as duas grandes datas que não se devem esquecer, 07 de setembro de 1822, data da independência nacional, e o 7 de setembro de 1922, data da comemoração do centenário dessa independência. No bloco de granito que apoia o livro está gravado o escudo do estado. $\bigcirc$ Povo aparece dirigindo-se à Pátria e oferecendo-lhe um ramo de louro. O louro simboliza a vitória e a paz conquistadas no país, conquistas estas garantidas pela força que a espada representa. A espada, entretanto, aparece embainhada, denotando muito mais sinal de defesa, a ser usada em reação a um suposto invasor, do que aspiração expansionista ou agressiva, conforme interpretou um dos comentadores do monumento: "a espada em descanso poderia ser invocada a qualquer instante em defesa própria". ${ }^{73}$

Todo esse conjunto escultórico repousa sobre um pedestal de base quadrangular com 2,60 metros, com três degraus. Nas quatro faces desse pedestal se encontram quatro medalhões de bronze, sendo um deles dedicado ao Padre Miguelinho, com a inscrição "7 de setembro de 1822 - 7 de setembro de 1922. O Primeiro Centenário da Independência da Pátria. Aos que trabalharam e a fizeram"; e outro destinado ao Imperador Dom Pedro I. Na base do monumento aparecem gravadas as seguintes inscrições latinas: "Potyguarensium genus / Duras naturae vices perferendo / Fortins factum / Et filiórum robere fultum, / Erit semper termis sed indefessus / Patriae unitatis et magnifudinis / Factor...". 74

Desenhos ornamentais espalham-se por toda a peça, simbolizando qualidades profundas do republicanismo, como a palma, símbolo do martírio; a oliveira, denotando o sacrifício; e o carvalho, representando a fortaleza. ${ }^{75} \bigcirc$ que chama atenção no novo monumento é sua preocupação em transmitir ideias abstratas como liberdade, justiça, memória e heroísmo. Para isto, fez-se uso de representações
72. Revista do Instituto Histórico e Geográfico do Rio Grande do Norte (1922, p. 142).

73. Ibid., loc. cit.

74. Ibid., p. 142. O historiador Itamar de Souza (2008b, p. 155) traduziu esse registro da seguinte forma: "O Rio Grande do Norte, fortalecido pela luta contra a natureza e amparado pelo vigor dos seus filhos, será sempre um pequeno, mas incansável operário da união e da grandeza da Pátria. Sejam quais forem os seus cuidados, quer o infortúnio te atormente, quer a felicidade te eleve, terás sempre a Pátria ante os olhos; por ela darás a tua inteligência, as tuas forças e até a tua vida”.

75. Ibid., p. 142. 
76. Carvalho (1990)

77. Ibid., p. 89-96.

78. Meneses (1994, p. 18) definiu a conotação que essa noção estabeleceu no país, como aquele em que "quaisquer que sejam seus atributos intrínsecos, por sentido prévio e imutável que o impregna, derivado, não desses atributos, mas de contaminação externa com alguma realidade transcendental - por exemplo, a 'vinculação a fatos memoráveis da história do Brasil', [...] na expressão do Decreto-lei 35, de 1937 , que criou o SPHAN Serviço do Patrimônio Histórico e Artístico Nacional". Assim, esses objetos apresentariam uma natureza sociológica própria, sendo "singulares e auráticos, na expressão benjaminiana ou, mais precisamente, não-fungíveis. Não poderiam ser substituídos por cópias ou por objetos de atributos equivalentes. São excluídos de circulação e não só têm o seu valor de uso drenado, como trazem para qualquer uso prático eventual a pecha do sacrilégio". alegóricas, diferenciando-se imensamente das anteriores que buscavam conferir uma representação figurativa e realista dos personagens homenageados.

Esse aspecto parece assinalar certo alheamento das elites republicanas em relação à população em geral. Apesar do farto uso pedagógico de alegorias na iconografia republicana francesa oitocentista, os republicanos brasileiros parecem não ter tido o mesmo êxito ao transplantar o modelo para o país. Ao analisar o uso da figura feminina como imagem da República no Brasil, José Murilo de Carvalho $^{76}$ atentou para o fracasso da transposição da Marianne francesa. Para ele, considerando as observações teóricas de Bronislaw Baczko, faltavam raízes, uma "comunidade de imaginação" para que esses símbolos e alegorias prosperassem. Além disso, Carvalho aponta outro fator que teria pesado para o insucesso: diferente da França, onde as mulheres tiveram presença importante nos movimentos revolucionários, no Brasil essa participação havia sido inexpressiva. ${ }^{77}$

\section{IDENTIFICANDO OBJETOS E LUGARES DA HISTÓRIA}

O sentido que permeou as ações dos membros do IHGRN passava por um novo olhar sobre o mundo material: o de reconhecer as particularidades de certos objetos e espaços a partir de uma relação privilegiada com o passado. Nesse contexto, a noção de objeto histórico emerge como uma categoria central na ação dos historiadores do instituto. ${ }^{78}$

Caberia ao historiador, primeiramente, identificar esses objetos ditos históricos em meio aos objetos cotidianos; em seguida, oferecer-thes um novo tratamento a fim de apagar qualquer sentido de uso. Para isto, eles deveriam ser retirados de circulação e conduzidos a um espaço construído especificamente para evocar seu novo sentido enquanto objetos eminentemente simbólicos.

A história da identificação desses objetos foi marcada por diferentes experiências, uma vez que alguns deles estavam completamente ausentes da vida social, enquanto outros foram encontrados desempenhando ainda antigas funções.

Um caso importante foi o achado de uma das cruzes de madeira de demarcação dos limites da cidade, que haviam sido cravadas pelas autoridades portuguesas ainda nos primeiros tempos de ocupação do território potiguar. A descoberta teria sido realizada por três jovens irmãos na segunda metade do século XIX, quando adentraram a Mata da Bica em busca de madeira para construir uma 
casa. Na ocasião, os jovens se "depararam com a cruz no seio da floresta, enrolada nas fitas das folhagens". 79

Foi no início do século XX que autoridades da lgreja Católica tomaram para si a responsabilidade pelo objeto encontrado, emprestando-lhe um sentido cada vez mais de relíquia, conforme o emprego da denominação "Santa Cruz da Bica". sentido religioso foi acompanhado pela necessidade de trasladar o objeto do antigo local à margem do rio da Passagem, ou do Baldo, para "um pouco mais abaixo da encosta-sul da área urbana", em decorrência dos serviços de abastecimento de água da cidade, realizados pela Empresa D'água Natal. ${ }^{80}$

que chama atenção no caso relatado é que a importância dada ao achado não estava inicialmente relacionada ao seu "valor histórico", mas ao seu sentido de relíquia, de objeto mágico-religioso. Ainda segundo o relato, depois de fixada na nova localidade a cruz passou a ser cultuada por populares e administrada pelas autoridades religiosas. "Um dos fiéis tirava o terço, cantado pelo povo, com acompanhamento musical. A devoção se espalhou e, a cada ano, crescia o número de assistentes, pagando promessas". ${ }^{81}$

Somente duas décadas após a transferência da cruz, em um artigo sobre o objeto publicado na revista do IHGRN, o secretário-geral da instituição, Nestor dos Santos Lima, atentou para seu valor histórico. Para ele, a "Santa Cruz da Bica" era igualmente importante por suas propriedades testemunhais, constituindo assim

um dos marcos da fundação de Natal [...], embora em fragmentos: é a Santa Cruz da Bica, em cujo caixilho, renovado há poucos anos, estão guardados os fragmentos da primeira cruz, que provavelmente ali plantou o destemido fundador da nossa urbs. ${ }^{82}$

Outra experiência deve ser destacada. Em sua História da cidade do Natal, Câmara Cascudo apontou para o fato de que, em plena segunda metade do século XX, a maioria dos natalenses desconhecia aquele que seria "o documento mais nobre" da capital do estado: o "pelourinho da Cidade". ${ }^{83}$ Segundo Cascudo, até o início do século XIX esse pelourinho ainda desempenhava sua função original associada à punição de infratores e criminosos, mas a partir da segunda metade do século esta função foi entrando em declínio, até desaparecer completamente qualquer referência a este sentido. "Derribado, em meados do século XIX, O pelourinho foi recolhido à casa da guarda da Cadeia Pública e aí serviu de banco durante longuíssimos anos", relata o historiador. ${ }^{84}$
79. Cascudo apud Souza, op. cit., p. 135-136.

80. Revista do Instituto Histórico e Geográfico do Rio Grande do Norte (19261927 , p. 110).

81. Cascudo apud Souza, op. cit., p. 136.

82. Revista do Instituto Histórico e Geográfico do Rio Grande do Norte (19261927 , p. 110).

83. Cascudo (2010).

84. Cascudo, op. cit., p. 457 , grifo meu. 
85. Cascudo, op. cit., p. 454.

86. Cascudo (1934, p. 6).
Foi, entretanto, em julho de 1904 que os membros do IHGRN trouxeram o objeto para a sede da instituição, a fim de registrá-lo como parte da coleção de objetos de valor histórico da capital. Meio século depois, Câmara Cascudo, recém-intitulado "historiador oficial da cidade", registrou esse processo e advogou em favor de promover o pelourinho a principal símbolo da autonomia política do município.

Na varanda do Instituto Histórico está uma coluna de alvenaria, sem topo nem remate artístico, fincada em exposição permanente. Quase ninguém dá por ela. É o documento mais nobre da Cidade. Símbolo de sua autonomia e jurisdição municipal atesta a presença da justiça permanente e os direitos da população governar-se por intermédio de seus eleitos.

É o pelourinho da Cidade do Natal. ${ }^{85}$

Outra iniciativa semelhante, e das mais conhecidas, foi a visita de uma comissão do IHGRN à região de Touros (cerca de 90 quilômetros ao norte da capitall na busca por identificar um antigo marco de pedra utilizado pelos representantes da coroa portuguesa para delimitar o território conquistado. Apesar de não ter sido um objeto proveniente do território da cidade, o fato é que a entrada do instituto na questão tornou cada vez mais forte o papel que a capital do estado deveria desempenhar no processo de definição e guarda desses artefatos históricos. A ação da instituição nesse caso era justificada pela necessidade de garantir a preservação da integridade física do objeto e pela obrigação de assegurar sua permanência no estado, tendo em vista o interesse manifestado por alguns estudiosos em transferi-lo para a capital do país.

Do mesmo modo que a Santa Cruz da Bica, as primeiras notícias sobre aquilo que seria denominado posteriormente de "Marco de Touros" atestavam a significação e utilização do objeto por grande parte da população local de Touros. Para esses populares, o marco era considerado "uma pedra santa", capaz de atender aos pedidos de devotos e penitentes.

O primeiro registro histórico do marco realizou-se ainda na última década do século XIX, pelo historiador pernambucano José de Vasconcelos. A descoberta foi comunicada no mesmo período ao Instituto Histórico e Geográfico Brasileiro (IHGB), onde se aventou a proposta para que a instituição nacional solicitasse do Ministério da Instrução Pública a remoção da peça para sua sede, no Rio de Janeiro. ${ }^{86}$

Foi somente na década de 1920 que o IHGRN criou uma comissão para colher informações mais precisas sobre o objeto. A comissão formada pelo 
próprio secretário-geral da entidade, Nestor dos Santos Lima, além de Câmara Cascudo e mais quatro membros, realizou uma série de exames na peça, os quais consistiam em: descrição da estrutura morfológica e das inscrições nela contidas; medição de suas proporções; estabelecimento de sua coordenada geográfica; e registro documental fotográfico.

Coube a Câmara Cascudo apresentar o relatório em que oferece um estudo das origens históricas do marco, a partir de documentos e obras do período colonial. Esse estudo procurava, além de tudo, atestar a primazia do objeto como "o mais antigo encontrado no território nacional". Em 6 de setembro de 1928, o trabalho foi publicado no principal jornal de circulação do estado, A República, para ciência dos natalenses. ${ }^{87}$

Na construção de uma identificação do espaço com a história, compreendida muitas vezes como memória, outro aspecto se destaca: a busca pelo reconhecimento de "sítios históricos". Estes seriam tomados como lugares portadores de uma relação privilegiada com determinado personagem ou fato digno de nota ocorrido no passado, ou seja, espaços reconhecidos pelo saber histórico, possuindo um valor peculiar, o "valor histórico". Assim, do mesmo modo que os membros do IHGRN se mobilizaram para reconhecer objetos de valor histórico na cidade, também o fizeram no sentido de identificar esses espaços. As ações desempenhadas pelo instituto se direcionaram para a busca de informações que pudessem definir algum lugar vinculado a heróis ou acontecimentos históricos no território potiguar.

Nesse sentido, uma importante iniciativa do IHGRN foi identificar a casa onde nasceu o herói republicano Frei Miguelinho. Em 1908 seria criada uma comissão especial para cuidar da questão. A partir de algumas referências iniciais sobre a possível localização da antiga residência, os membros da comissão realizaram uma série de visitas ao bairro da Ribeira buscando identificar o local. Porém, depois de muitas idas e vindas, os integrantes da comissão chegaram à desanimadora constatação de que a residência não mais existia:

tendo procedido a escrupulosas e diligentes pesquisas, no empenho de realizar a verdade, em ordem a poder o Instituto Histórico, [...] chegou à convicção de que, infelizmente, não existe mais este prédio, que, segundo informações fidedignas e de pessoas de mais adiantada idade, fora situado no bairro da Ribeira desta cidade, na rua sítio de coqueiros que ali existira entre a propriedade da finada d. Maximina Barroca e o ponto conhecido por "Canto da Ribeira". 88

A constatação da inexistência do prédio veio acompanhada por um sentimento de abatimento entre os membros da instituição, a ponto de, na conclusão
87. Cascudo apud Melo (1950, p. 18).

88. Revista do Instituto Histórico e Geográfico do Rio Grande do Norte (1908, p. 330-331). 
89. Estranhamente (conforme veremos adiante), anos antes, em 1906, O IHGRN havia celebrado os 89 anos de aniversário de morte do Frei Miguelinho, em que teria desvendado uma lápide comemorativa em frente à casa onde ele nasceu. É mais provável que posteriormente a este fato descobriu-se que a referida casa não era autêntica, o que teria levado os membros do instituto a uma nova investida, em busca da verdadeira residência.

90. Souza (2008b, p. 119). do relatório apresentado, pedirem desculpas aos demais confrades por não poderem dar uma notícia mais entusiástica. Entretanto, a frustração não levou à passividade, pois novas comissões se formariam a fim de empreender outras diligências a lugares dessa natureza e de buscar objetos que possuíssem algum "valor histórico". 89

A princípio, a busca por objetos e sítios do passado parecia esbarrar no processo de transformações urbanas em curso na cidade, onde antigas edificações estavam sendo demolidas para dar lugar a novas, e a paisagem secular ia sofrendo contínuas alterações pela reorganização do espaço urbano. A partir de 1908, durante o segundo governo de Alberto Maranhão, essas ações se tornaram mais frequentes.

Conforme vimos, ainda no início do século XX, devido às obras realizadas pela Empresa D'água Natal na região do Baldo, a cruz chantada originalmente na margem do Rio da Bica foi trasladada para outro local na margem direita do rio Potengi. No ano de 1914, durante a administração de Ferreira Chaves, uma das primeiras sedes do governo provincial, localizada na Rua da Conceição, foi colocada abaixo para a construção da praça Sete de Setembro. O mesmo fim teve uma antiga residência dos capitães-mores situada na praça André de Albuquerque, demolida em 1930.90

Até mesmo velhos edifícios particulares, como o da sede do jornal Correio de Natal, foram demolidos para dar lugar a construções modernas como a do Palácio Felipe Camarão, sede da Prefeitura Municipal, inaugurada em 1922. Também a abertura de novas ruas e o prolongamento de antigas avenidas, como a Rio Branco e a Princesa Isabel, levaram à extinção de sítios e vivendas particulares centenárias.

Porém, seria por demais precipitado enfatizar o choque que essas mudanças urbanas possam ter causado sobre as antigas construções do passado. Diferentemente do que havia ocorrido em algumas capitais de outros estados brasileiros, como Rio de Janeiro, São Paulo, Salvador e Recife, as intervenções urbanas na capital potiguar foram bem menos impactantes nesse sentido. Em parte isso pode ser explicado pela pouca quantidade de edifícios antigos existentes em Natal no período.

Em um artigo escrito no final da década de 1940, Câmara Cascudo faz um balanço da presença de antigas edificações no território natalense, chegando à seguinte constatação: 
Atualmente não existe em toda a cidade uma só casa que date do século XVIII. Todas são posteriores a 1800. Excetuando-se as Igrejas, naturalmente...

Do próprio século XIX apenas os edifícios públicos reformados e conservados vão durando. As casas particulares são raras. De 1801 a 1850 não conheço uma sequer. De 1850 em diante lembro apenas de duas. ${ }^{91}$

O historiador associava a efemeridade das antigas edificações natalenses à fragilidade dos materiais de construção nelas utilizados; a maioria delas era feita de barro e galhos de árvores, e poucas eram construídas com materiais mais resistentes ao tempo, como pedra.

Com as ações de renomear ruas e construir novos logradouros, erguer monumentos e inventariar objetos históricos no interior da cidade, os membros do IHGRN estabeleciam um novo quadro de referências simbólicas e materiais que deveriam mudar profundamente os hábitos e as percepções cotidianas da população da capital. Porém, essas mudanças tornaram-se socialmente mais significativas quando encenadas através das comemorações cívicas, rituais importantes na criação de um novo referencial de memória e de identificação coletiva.

\section{RITUAIS DA MEMÓRIA NO TERRITÓRIO DA CIDADE}

A partir da primeira década do século XX as celebrações cívicas tiveram curso na vida dos natalenses, especialmente pela capacidade de mobilização da população local, e reuniram não só a elite ilustrada, a exemplo dos membros do IHGB e das autoridades governamentais e eclesiásticas, mas sobretudo os diversos grupos e elementos da sociedade civil, como escolas, grêmios estudantis, irmandades religiosas, entidades desportivas, associações classistas, grupos de escoteiros, entre outros.

Em uma dessas cerimônias, a que homenageava os 89 anos de aniversário de morte de Frei Miguelinho, uma série de atividades foi realizada. Pela manhã, as bandas de música da capital apresentaram uma alvorada, acompanhada por uma salva de 21 tiros e girândolas na praça André de Albuquerque, seguida por uma missa campal em frente à porta da Matriz. Depois disso, um préstito cívico foi até o local onde havia sido sacrificado o padre republicano, momento em que "uma guarda de honra formada por autoridades e representantes do Instituto 
92. Revista do Instituto Histórico e Geográfico do Rio Grande do Norte (1906, p. 313).

93. Ibid.
Histórico e Geográfico foi acompanhada pelo Batalhão de Segurança que juntamente com outras bandas de músicas presentes tocaram o hino nacional". ${ }^{92}$

A simbologia e a incorporação da memória podem ser avaliadas na formação do cortejo cívico, organizado em treze alas. Algumas delas representavam um herói ou um acontecimento histórico e eram municiadas por insígnias e bandeiras:

\begin{abstract}
A primeira trazia a Bandeira da Revolução de 1817, guardada por um piquete de lanceiros e precedida de um clarim. A segunda, formada pela Banda de Segurança. A terceira ala conduzia o estandarte de André de Albuquerque, que foi protegida por oficiais do $2^{\circ}$ Batalhão de Infantaria, de Segurança e da Guarda Nacional. A quarta ala era composta pela banda de música "1 2 de Outubro", da capital. Uma quinta ala trazia o Estandarte de Felipe Camarão, protegido pelas sociedades dos Empregados do Comércio, Liga Artístico Operária, Mocidade Católica, Grêmio Tobias Barreto entre outras agremiações civis. Uma outra banda de música acompanhava o cortejo, a Banda "3 de Maio". A nona ala era representada pelo Estandarte Clara de Castro e protegida pelos alunos do colégio Santo Antônio, seguida pela banda de música "Antônio Andrade". O último estandarte foi destinado a homenagear Frei Miguelinho. Guardado por 37 senhoritas que representavam os municípios do Estado do Rio Grande do Norte. ${ }^{93}$
\end{abstract}

A cerimônia assinalava a importância de Frei Miguelinho e do acontecimento de 1817 na definição da memória republicana. Por outro lado, também permitia relacionar as instituições atuais e esse passado, por meio da associação entre as alas, com suas insígnias, bandeiras e respectivas entidades. É importante apontar o peso da execução musical, do uso de uniformes, da condução de bandeiras e de outros artefatos simbólicos no processo de incorporação da memória.

A formação das alas oferece uma dimensão das instituições que deveriam presidir a sociedade republicana. A presença de militares à frente de algumas alas denota o lugar que essa instituição possuía na estrutura social, porém, estava longe do caráter militarista que se tornaria cada vez mais comum nas cerimônias cívicas com a instalação do Estado Novo.

Também é importante considerar que, apesar de a cerimônia ter como finalidade homenagear a figura do Frei Miguelinho, ela procurou associar seu nome ao de outras figuras emblemáticas, instituindo assim a ideia de um panteão republicano.

Este ritual criava a sensação de que cada indivíduo compartilhava de uma fraternidade cívica, mesmo que isso significasse suspender sua individualidade e idiossincrasias. A formação em filas, a uniformização, o uso de estandartes e de insígnias era uma tentativa de enquadrar os indivíduos em certas modelações sociais. Assim, a forma de organização por alas não deixa de transparecer um 
sentido corporativo de sociedade, em que cada categoria social e socioprofissional se apresenta como parte constitutiva de um conjunto social maior. Portanto, essas cerimônias aparecem como exercício tanto de autodisciplina daqueles que nela tomam parte, quanto de disciplina social, ao incorporar as hierarquias sociais existentes e os comportamentos esperados no espaço público. ${ }^{94}$

Essa cerimônia percorreu as principais ruas da cidade, saindo da praça André de Albuquerque, núcleo fundador da urbe; atravessou toda a Cidade Alta até descer ao seu outro extremo, o bairro da Ribeira, na rua Treze de Maio, mais especificamente em frente à "casa que nasceu Frei Miguelinho". Neste lugar foi realizada uma nova solenidade de descerramento da "lápide comemorativa do nascimento e sacrifício do herói", pelo governador do estado e pelo presidente do instituto. Em seguida a solenidade foi entregue ao presidente da Intendência Municipal. A execução do Hino Nacional Brasileiro pelas bandas e a salva de 21 tiros marcaram o término. $O$ préstito seguiu pela Rua do Comércio e pela rua Chile, dissolvendo-se em frente ao Teatro Carlos Gomes.

$\bigcirc$ deslocamento no território da cidade permitia não só a performance dos participantes, mas também que o ritual atingisse aqueles que não quiseram ou não puderam participar diretamente dele. Era uma forma de irradiar o simbólico para além dos nichos em que ele havia sido previamente concebido, ao mesmo tempo que trazia a esses participantes a legitimidade social, através dos aplausos e da atenção pública. ${ }^{95}$

Ainda sobre os festejos a Frei Miguelinho, as comemorações adentraram pela tarde e noite, sendo encerradas com uma sessão de homenagem no $\|$ HRN. "Na sessão foi cantado, por 37 senhoritas que representavam os municípios do Rio Grande do Norte, um hino, feito exclusivamente para homenagear o herói republicano". A festa chegou ao seu final com a recitação, por um membro do instituto, o poeta Segundo Wanderley, de uma composição sua sobre o herói potiguar, que em seguida foi colocada "em lugar devidamente preparado, a estola que o grande mártir usou nos últimos anos de sua vida heróica". 96

Em outra cerimônia, a de inauguração da herma do Padre João Maria, realizada pelo $1 H G R N$ em 1917, todos os presentes puderam ver e ouvir ao final da apresentação o momento em que "uma aluna do Asilo João Maria leu uma poesia análoga ao ato e o Dr. João Soares, da janela de um prédio vizinho, terminou a série de manifestações, pronunciando belas palavras sobre a ação caritativa do padre João Maria". 97

Conforme vimos, esses rituais foram sempre marcados por um alto grau de teatralidade. Os cenários em que eles eram executados eram preparados com ornamentos, adereços e insígnias. As pessoas que deles participavam muitas vezes
94. Cf. Ryan (1992).

95. Cf. Segalen (2002).

96. Wanderley (1950, p. 379).

97. Revista do Instituto Histórico e Geográfico do Rio Grande do Norte (1919a, p. 198). 
98. Connerton (1993, p. 81).

99. Cf. Offerlé (2005). dispunham de uma atuação previamente definida. Também nesses rituais a retórica verbal desempenhava um papel central. $\bigcirc$ ato de proferir discursos, recitar poesias, bradar palavras de ordem acompanhadas sempre por uma panóplia gestual, mostrava-se mais do que um simples meio de organização da memória pessoal e coletiva: tratava-se de um modo de habituação corporal. ${ }^{98}$

Dentre as cerimônias que mobilizaram os membros do instituto e todo o poder constitutivo do município e do estado, a comemoração do Centenário da Independência do país foi a que mais se destacou. $\bigcirc$ evento impressionou pela dimensão social e simbólica que assumiu na cidade, não só pelos oito dias dedicados à celebração, mas pela mobilização social que ela envolveu.

Diferente das anteriores, a programação foi organizada em oito temas, de modo que cada dia do festejo seria dedicado a um tema específico: o primeiro foi consagrado à "colonização"; o segundo à "prosperidade"; o terceiro à "força"; o quarto às "artes"; o quinto à "pátria"; o sexto ao "trabalho"; o sétimo ao "futuro"; e o oitavo à "história". Para cada dia havia um conjunto de atividades específicas em torno do tema. Na manhã do primeiro, visitou-se a Fortaleza dos Reis Magos, onde foi fixada uma lápide comemorativa. À tarde foi organizada uma festa marítima no estuário do Potengi, acompanhada por um torneio de remo, natação e outros jogos, sendo encerrada à noite com uma "festa veneziana". $\bigcirc$ segundo dia foi dedicado às atividades econômicas, sobretudo ao comércio e à indústria local. Na ocasião, realizou-se uma exposição de "produtos regionais" de produtores e comerciantes do estado.

Os demais dias seguiram-se numa extensa programação cobrindo todos os turnos com atividades variadas, não apenas no centro da cidade, mas também nos bairros. Essas ações eram as mais diversificadas, indo de apresentações militares, com alvoradas e salvas de tiros, passando pela celebração de missas, prática de atividades desportistas até inauguração do novo "Palácio da Municipalidade" no bairro da Ribeira e do monumento da Independência na praça Sete de Setembro. Além das atividades cívicas propriamente ditas, o evento foi permeado por um caráter festivo, com queima de fogos de artifício, apresentação de retretas, exibições cinematográficas ao ar livre e outras diversões populares.

A cerimônia marcou a consagração do sentimento patriótico entre a população da cidade. Não só afastava cada vez mais qualquer manifestação de provincianismo separatista que viesse colocar em risco a integridade nacional, como também aprofundava o processo de cidadania cívica ao promover a nacionalização do cidadão. Assim, apesar de cada participante vivenciar uma experiência particular, esta se tornava intercambiável às outras cerimônias similares realizadas no mesmo momento em todo o território nacional. ${ }^{99}$ 
Conforme vimos, essas experiências cívicas nunca chegaram a ser consensuais entre as próprias elites republicanas. Alguns, como Felipe Guerra, chefe político seridoense e um dos representantes da oposição à oligarquia Alberto Maranhão, expressou com contundência em um jornal local sua contestação a todas aquelas edificações e cerimônias cívicas, vendo nelas apenas o desperdício dos recursos públicos, movido pela vaidade do grupo dirigente local:

Essa idéia de monumentos na capital, quando urgentíssimas necessidades reclamam a aplicação dos minguados recursos do Estado, é por certo infeliz e impatriótica. Apenas lisonjeia a vaidade dos governantes, e é mais aparatosa. É mal velho da Humanidade [...] O monumento aí fica, sob as vistas de seus iniciadores, algum tempo: placa comemorativa na fachada, inauguração, músicas, foguetes, discursos, uma apoteose capaz de trazer a ilusão de imortalidade! Os serviços modestos, aqueles que com aparência de insignificantes muitas vezes representam o primeiro e vacilante passo para o início da prosperidade de um povo, para uma regeneração de costumes, a primeira e débil semente que frutificará com certeza, embora em mais ou menos remoto futuro, esses cometimentos não calam nos sentidos e na inteligência daqueles que se deixaram impressionar pelos matizes das bolhas de sabão, ou pelo estardalhaço dos fogos de artifício, embora o vácuo e as trevas se tenham de estabelecer minutos após. Os empreendimentos que visam o aperfeiçoamento e o bem social, embora pela própria natureza das coisas de vagoroso desdobramento, são os mais belos monumentos a honrar a memória dos seus iniciadores e dos seus continuadores. Lembrem-se os que tem a direção da coisa pública, no Estado, que as humildes e sofredoras classes que representam a pequena lavoura, a criação, o pequeno comércio, e a agricultura, formam o alicerce do edifício social: as suas ocupações, os seus labores, os seus sofrimentos, não thes dão tempo para engrossamentos; mas os seus queixumes, as suas reclamações também ecoam nas páginas da História; e é pela confrontação de todos, os fatos, pelo exame de todas as vozes que ela, afinal, faz a Justiça. $\bigcirc$ monumento assim como pode atestar a grandeza, pode atestar a pequenez. Para um estado sem letras, sem escolas, com uma população de analfabetos, sem indústria, sem estradas, flagelado por crises de fome e de sede, não é dado cuidar de arte e literatura: seria principiar a edificar pela cúpula. ${ }^{100}$

As admoestações de Felipe Guerra não eram caso isolado ou mesmo pessoal; faziam parte de uma frequente oposição à política de memória estabelecida pelos Albuquerque Maranhão. Apesar disso, essas contestações não foram capazes de barrar ou sequer atenuar a nomeação de logradouros, a construção de monumentos e as cerimônias cívicas. Assim, mesmo depois de 1914, quando os Albuquerque Maranhão perderam o comando do estado, as celebrações cívicas continuaram presentes na vida da capital. Os festejos do Centenário da Independência do país realizados durante a gestão do presidente Antonio José de Mello e Souza (1920-1924), ex-aliado dos Albuquerque Maranhão, dão prova da continuidade desse processo.
100. Guerra apud Arrais (2006, p. 128-129). 
101. Cunha (2015).

102. Ibid.

103. Trata-se de um conjunto de acontecimentos violentos ocorridos em Barcelona e em outras cidades da Catalunha entre 26 de julho e 2 de agosto de 1909, envolvendo o exército e operários, em decorrência da resistência destes últimos à mobilização das tropas reservistas para reforçar as tropas espanholas na guerra colonial no Marrocos.

104. Souza (2008a, p. 145147.
Dessa forma, em 1924, quando um novo grupo político liderado pelo recém-eleito presidente do estado, José Augusto de Medeiros, chegou ao poder, as práticas de nomeação, bem como a edificação de monumentos e as comemorações cívicas foram retomadas. Elas deixaram de estar circunscritas à capital e passaram a fazer parte também da vida pública das pequenas e médias cidades do interior do estado.

Por outro lado, a imagem de consenso criada por essas cerimônias não impediu que viessem à tona momentos de forte contestação da ordem social. Um ano depois dos festejos do Centenário da Independência, Natal e outras importantes cidades do estado foram tomadas por uma onda de movimentos de reivindicação trabalhista e sindical. Em 1923, a capital parou devido à greve geral. $\bigcirc$ protesto reuniu diversas categorias profissionais de trabalhadores urbanos: estivadores do porto, operárias da fábrica de tecidos, panificadores, carregadores, jornaleiros, entre outras. Para Paulo Rikardo Cunha, ${ }^{101}$ o momento teria sido marcado pela união momentânea dessas categorias profissionais em torno de um objetivo comum. Com a greve geral teriam aflorado noções e sentimentos de identidade e alteridade em relação aos grupos dominantes, evidenciando assim as tensões entre trabalhadores urbanos, patrões e lideranças políticas. Os grupos mais radicais do movimento não só questionaram a precária situação de trabalho e as condições de sobrevivência, como também propuseram subverter a ordem social. Essas manifestações vinham lembrar o tênue equilíbrio social afirmado pelos republicanos. ${ }^{102}$

Apesar de predominar o caráter oficial dessas cerimônias, algumas delas chegaram a extrapolar esse aspecto e até assumiram uma dimensão vernacular. Um dos acontecimentos emblemáticos ocorreu no dia 24 de outubro de 1909, quando um grupo de intelectuais locais composto pelos poetas Gothardo Neto e Ferreira Itajubá, além de Paulo Maranhão, Dioclécio Duarte, Álvaro China e Vicente Barreto, perante uma multidão instalada na praça André de Albuquerque homenageou a memória do pedagogo e anarquista catalão Francisco Ferrer Guardia, fuzilado na Espanha por ordem do rei Afonso XIII após ser acusado de instigar a revolta conhecida como Semana Trágica de Barcelona. ${ }^{103}$ Conforme noticiou o jornal A República, após um comício os organizadores saíram em passeata pelas ruas da Cidade Alta e da Ribeira, ao som da banda de música do Batalhão de Segurança. Durante a manifestação os participantes deram vivas a Ferrer, à República e às ideias socialistas. ${ }^{104}$

A imagem paradoxal desse evento em homenagem ao líder anarquista espanhol nas ruas de Natal nos dão ideia do caráter dual da memória pública, em que uma dimensão hegemônica aparece acompanhada por uma multivocalidade de 
memórias não oficiais. Matthew Houdek e Kendall Phillips já haviam assinalado que, embora as comemorações sejam largamente ditadas dentro de quadros oficiais e socialmente aceitos, elas podem servir como oportunidades de intervenção e crítica social. As tensões entre memórias oficiais e vernaculares (ou populares) podem até criar condições para que a comemoração mude de significado, função e importância. ${ }^{105}$

É difícil definir o impacto social que as experiências cívicas tiveram sobre a população local. Sabemos que, apesar de algumas lideranças republicanas expressarem a necessidade de participação popular na vida cívica, nem sempre esses apelos eram significativos para mobilizar toda a população. Em um relatório deixado pelo presidente do estado, Antonio José de Mello e Souza, sobre os festejos cívicos do Centenário de Independência na capital, ele chegou a lamentar às autoridades nacionais que, apesar dos esforços empreendidos pelo poder público para garantir um maior número possível de participantes, os resultados teriam ficado muito aquém do esperado. ${ }^{106}$ Para Souza, essa falta de interesse estava ligada à permanência de uma mentalidade ainda fechada "à rotineira vida comunal, de que só a publicação dos orçamentos municipais, exigida pela lei, nos dá anualmente um longínquo indício"; uma mentalidade em que "o município, o Estado, a Nação, são entidades um tanto indeterminadas, das quais pouco mais conhecemos que o imposto e a polícia, e dificilmente compreendemos que por elas se deva sacrificar um pouco do interesse de cada um". ${ }^{107}$

Não se pode deixar de reconhecer que havia dificuldade em despertar o envolvimento popular nessas celebrações. Conforme vimos, o uso de alegorias complexas e inscrições em latim nem sempre teve o efeito esperado sobre a população em geral. Em alguns momentos, o estilo neoclássico associado a referências greco-romanas ou mesmo europeias parece não ter sido o melhor meio de compartilhar ideias e valores entre a comunidade nacional. Em alguns estados do país, devido à dificuldade da população em compreender os códigos cerimoniais e o significado dos monumentos, tomava-se como recurso a distribuição de folhetos explicativos. No entanto, em Natal não há registro desse tipo de ação. É provável que todas as explicações possíveis ficassem a cargo dos oradores, que, devido ao contato limitado com o público nas apresentações, tinham dificuldade de passar a contento sua mensagem.

Numa de suas reminiscências, Câmara Cascudo lembra que quando criança assistiu a inauguração do monumento em homenagem a Pedro Velho, na praça que levaria seu nome. Segundo Cascudo, ao observarem o monumento os populares pensavam que a figura feminina inclinada para frente, ofertando um ramo votivo a Pedro Velho, representando a pátria norte-rio-grandense, era dona Nila, a viúva de líder republicano. ${ }^{108}$
105. Houdek; Phillips (2017.

\section{Souza (1922.}

107. Ibid., p. 36.

108. Cascudo apud Costa (2013, p. 79. 
109. Nesse aspecto, concordo com a interpretação de Marcelino (2011, 2016) a partir das reflexões de Mona Ozouf, de que as festas cívicas devem ser compreendidas para além da tentativa de controle por parte dos seus organizadores. Elas estariam muito mais relacionadas às necessidades coletivas de romper com o transcurso do tempo, projetando desejos para o futuro, do que a uma simples antecipação da realidade.
Apesar desses testemunhos, não se pode negar o impacto que todas essas celebrações tiveram sobre a população local. A fim de compreender a complexidade dessas experiências é importante tratá-las não apenas como simples imposição dos interesses das elites sobre a população em geral, mas pensá-las considerando as diferentes formas de participação dos sujeitos envolvidos. ${ }^{109}$ Assim, mesmo assinalando a importância central do IHGRN em todo esse processo, não se pode reduzir a riqueza dessa experiência a um simples dispositivo de dominação de classe ou coisa do tipo. Do representante do poder constituído aos bacharéis reformadores, dos comerciantes e funcionários públicos aos estudantes e escoteiros, dos esportistas às donas de casa, todos, à sua maneira, tinham nessas experiências um lugar de afirmação social. Independentemente da condição social ou intelectual, do local de moradia, da atividade profissional, essas cerimônias permitiam que naquele momento todos se sentissem como um único corpo social.

Numa Natal ainda pouco dada a aglomerações urbanas, as mobilizações cívicas, sobretudo a do Centenário de Independência do país, apresentavam-se como algo totalmente diferente de tudo que a cidade havia presenciado até então. A proliferação de monumentos em diversos pontos da capital potiguar e as celebrações cívicas a eles associadas permitiam a uma parte dos natalenses uma experiência nova de percorrer a cidade. A fronteira entre a Cidade Alta e a Ribeira desaparecia durante os cortejos cívicos, pois as linhas que passavam a unir os natalenses eram formadas pelo culto aos heróis republicanos do passado, cujos bustos, estátuas e hermas estavam espalhados por diversos pontos da urbe.

As novas experiências cívicas deflagradas pelo regime republicano na cidade de Natal, mais do que o aparecimento de novas estruturas urbanas e de novos hábitos, representaram uma importante mudança nas formas de identificação social da população. Elas estabeleceram uma maneira nova de encarar o passado e de constituir a memória coletiva. $\bigcirc$ passado, tempo distante, muitas vezes indefinido e pessoal, foi preenchido e transposto para o presente através dos rituais realizados. Do ponto de vista das identidades sociais, tal operação significou o estabelecimento de uma nova filiação para os habitantes da cidade, uma filiação que não deveria mais considerar a antecedência familiar, nem religiosa, e muito menos étnica ou de outra natureza, mas uma dada antecedência histórica firmada sobre antigos heróis e acontecimentos exemplares.

Em todas essas experiências a história aparece como uma disciplina importante, capaz de fornecer as memórias sobre as quais deveria se firmar a identidade dessa comunidade cívica e possibilitando o desenvolvimento de uma consciência histórica, entendida como uma forma da consciência humana por meio da qual os indivíduos "interpretam sua experiência da evolução temporal 
de seu mundo e de si mesmos, de forma tal que possam orientar, intencionalmente, sua vida prática no tempo". 110

Entre os novos sujeitos atuantes nas cerimônias cívicas estavam as mulheres. Estimuladas a participar da cena pública, muitas delas tinham nesses rituais a oportunidade singular de extrapolar os limites da casa e da vida privada. Ao enaltecer as escritoras por meio de bustos, placas e discursos, os rituais cívicos não só homenageavam essas figuras do passado, mas instigavam as jovens alunas a tomá-las como modelos femininos de êxito. Nas homenagens às escritoras, vê-se que os desejos femininos eram direcionados para o aprendizado escolar, o domínio das letras e também para o fortalecimento do espírito público.

Outro grupo social importante era o de pessoas negras e mestiças. Fotografias dos festejos testemunham a presença desses indivíduos como público expectador e também atuante. Para esse grupo, ainda fortemente estigmatizado pela escravidão, a presença nas festas e cerimônias cívicas representava uma possibilidade de garantir respeitabilidade social e ascender na sociedade urbana moderna. Diferentemente da experiência natalense, os festejos cívicos na Bahia foram acompanhados por manifestações populares de caráter mais espontâneo e tradicional, muitas vezes vistas pela elite letrada como expressão de resistência à modernidade e à civilização. ${ }^{111}$

As crianças também se apresentaram como agentes dessas celebrações. Sua participação foi estimulada pela importância que assumiu a educação cívica na escola republicana. Fossem essas crianças de bairros operários, como Alecrim e Rocas, ou mais abastados, como o da Cidade Alta, passaram a ser integradas à comunidade pública e vistas como futuros cidadãos. Os desfiles cívicos eram para as crianças, assim como para os adultos, uma experiência que ficaria marcada para sempre em suas memórias pessoais, funcionando como importante meio de incorporação da simbologia republicana e como uma nova maneira de perceber a cidade.

Por fim, se por um lado essas experiências não deixaram de produzir uma tendência conformativa nos indivíduos, por outro, mesmo o caráter cerimonial e oficial desses eventos sempre foram marcados por uma dimensão festiva e às vezes até informal. Os desfiles cívicos, mesmo introduzindo certo grau de solenidade por meio de alas e da organização dos participantes em filas, estavam longe do se constituírem como falanges ou corpus militarizados. Distante de adotarem a marcha, como se tornará comum nos desfiles cívicos e escolares posteriores, o que predominou foi a caminhada, um modo de percorrer o espaço de forma mais livre e autônoma. Algumas fotografias revelam que os participantes desses cortejos eram caminhantes que muitas vezes estavam sujeitos a mudar de trajeto quando se 
deparavam com algum obstáculo, como poças d'água, buracos nas ruas ou até mesmo com um transeunte desavisado.

No entanto, as atividades esportivas e de entretenimento, como os torneios de tiro ao alvo, natação e remo, as festas, exibições de filmes e apresentações de retretas demonstram que as cerimônias cívicas estiveram marcadas também por uma forte conotação lúdica e recreativa. Além disso, tais celebrações deixavam de ser rituais exclusivamente masculinos e de pessoas adultas, ou seja, de iniciados, para se tornarem cada vez mais abertas e marcadas pela participação de mulheres, jovens e crianças (Figura 2).

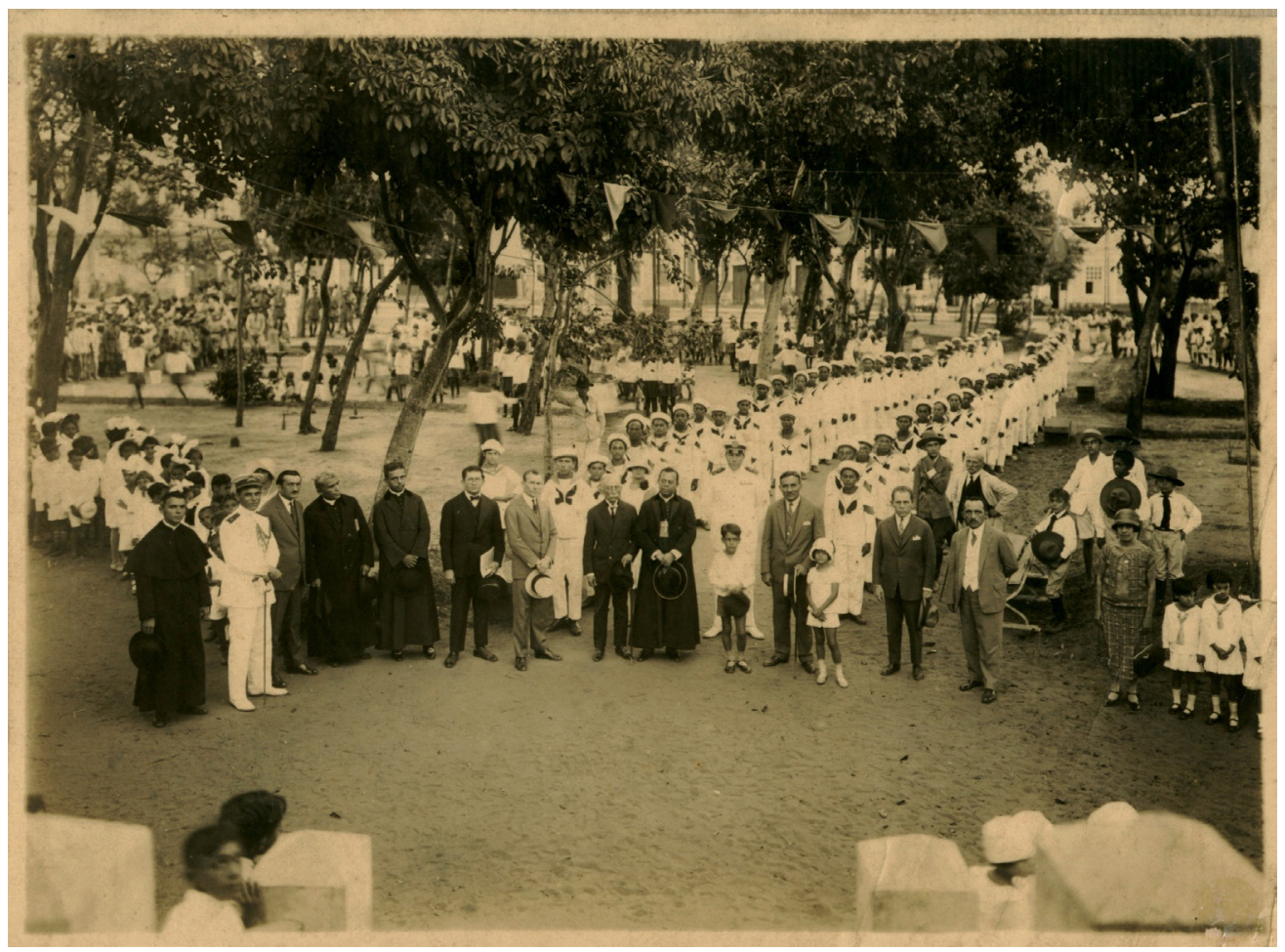

Figura 2 - Um dos diversos desfiles realizados durante a cerimônia do Centenário da Independência. $O$ préstito cívico concentrado na praça Augusto Severo, em frente à nova sede do poder estadual, foi recebido oficialmente pelo presidente do Rio Grande do Norte, Antonio José de Mello e Souza. A grande presença de crianças assinala a importância que esse grupo passou a ter nas cerimônias cívicas republicanas. Fonte: Acervo Fotográfico do IHGRN. Foto: J. Galvão. 


\section{REFERÊNCIAS}

FONTES IMPRESSAS

CASCUDO, Luís da Câmara. O marco colonial de Touros. In: MELO, José Alves de (org.). Natureza e história do Rio Grande do Norte (1501-1889). Natal: Imprensa Oficial, 1950. p. 17-18.

CASCUDO, Luís da Câmara. O mais antigo marco colonial do Brasil. Natal: Centro de Imprensa, 1934 .

CASCUDO, Luís da Câmara. História da cidade do Natal. 4. ed. Natal: EDUFRN, 2010.

REVISTA DO INSTITUTO HISTÓRICO E GEOGRÁFICO DO RIO GRANDE DO NORTE. Natal: IHGRN, v. 4, n. 2, 1906.

REVISTA DO INSTITUTO HISTÓRICO E GEOGRÁFICO DO RIO GRANDE DO NORTE. Natal: IHGRN, v. 6, n. 2, 1908.

REVISTA DO INSTITUTO HISTÓRICO E GEOGRÁFICO DO RIO GRANDE DO NORTE. Natal: IHGRN, v. 17, n. 1-2, 1919a.

REVISTA DO INSTITUTO HISTÓRICO E GEOGRÁFICO DO RIO GRANDE DO NORTE. Natal: IHGRN, v. 27, n. 1-2, 1919b.

REVISTA DO INSTITUTO HISTÓRICO E GEOGRÁFICO DO RIO GRANDE DO NORTE. Natal: IHGRN, v. 19, n. 1-2, 1922.

REVISTA DO INSTITUTO HISTÓRICO E GEOGRÁFICO DO RIO GRANDE DO NORTE. Natal: IHGRN, v. 23-24, 1926-1927.

SOUZA, Antonio José de Mello e. Mensagem lida perante o Congresso Legislativo na abertura da Segunda Sessão da Undecima Legislatura. Natal: Congresso Legislativo, 1922.

WANDERLEY, Jaime dos Guimarães. A estola de Frei Miguelinho. In: MELO, José Alves de (org.). Natureza e história do Rio Grande do Norte (1501-1889). Natal: Imprensa Oficial, 1950. p. 379-380. 
ABREU, Marcelo Santos de. Entre civismo e democracia: imagem republicana e poder simbólico. In: KNAUSS, Paulo (coord.). Sorriso da cidade: imagens urbanas e história política de Niterói. Niterói: Fundação de Arte de Niterói, 2003. p. 83-127.

AIRAGHI, Paulo Vitor Sauerbronn. José Leão Ferreira Souto e a construção da identidade potiguar na transição do século XIX para o século XX. 2016. Dissertação (Mestrado em História) - Universidade Federal do Rio Grande do Norte, Natal, 2016.

ALBUQUERQUE, Wlamyra R. de. Algazarra nas ruas: comemorações da Independência na Bahia (1889-1923). Campinas: Editora da Unicamp, 1999.

ANDRADE, Alenuska Kelly Guimarães. A eletricidade chega à cidade: inovações técnica e a vida urbana em Natal (1911-1940). 2009. Dissertação (Mestrado em História) - Universidade Federal do Rio Grande do Norte, Natal, 2009.

ARRAIS, Raimundo. A capital do Rio Grande do Norte no início do século XX. In: FERREIRA, Ângela Lúcia; DANTAS, Goerge (orgs.). Surge et Ambula: a construção de uma cidade moderna (Natal, 1890-1940). Natal: EDUFRN, 2006. p. 121-135.

BITTENCOURT, José Neves. Espelho da "nossa" história: imaginário, pintura histórica e reprodução no século XIX brasileiro. Tempo Brasileiro, Rio de Janeiro, n. 87, p. 58-79, 1986.

BODNAR, John. Remaking America: public memory, commemoration and patriotism in the twentieth century. Princeton: Princeton University Press, 1994.

BUENO, Almir de Carvalho. Visões de República: idéias e práticas políticas no Rio Grande do Norte (1880-1895). Natal: EDUFRN, 2002.

CARVALHO, José Murilo de. A formação das almas: o imaginário da República no Brasil. São Paulo: Companhia das Letras, 1990.

COELHO, Geraldo Mártires. No coração do povo: o monumento à República em Belém, 18911897. Belém: Paka-Tatu, 2002.

CONNERTON, Paul. Como as sociedades recordam. Oeiras: Celta, 1993. 
COSTA, Helensandra Lima da. A Família do tesouro: a monumentalização da família Albuquerque Maranhão e a luta pelo poder no Rio Grande do Norte (1889-1914). 2013. Dissertação (Mestrado em História) - Universidade Federal do Rio Grande do Norte, Natal, 2013.

CUNHA, Paulo Rikardo Pereira Fonseca da. Ombro a ombro com os mais fracos: a inserção de João Café Filho nos espaços do trabalhador na cidade do Natal (1921-1937). 2015. Dissertação (Mestrado em História) - Universidade Federal do Rio Grande do Norte, Natal, 2015.

DICKINSON, Greg; BLAIR, Carole; OTT, Brian. Places of public memory: the rhetoric of museum and memorial. Tuscaloosa: University of Alabama Press, 2010.

DOBERSTEIN, Arnoldo Walter. Estatuária e ideologia: Porto Alegre 1900-1920. 2. ed. Porto Alegre: Secretaria Municipal de Cultura, 2002.

FERNANDES, Saul Estevam. O (in)imaginável elefante mal-ajambrado: a retomada da questão de limites entre o Ceará e o Rio Grande do Norte e a formação espacial e identidade norterio-grandense (1894-1920). Natal: Editora IFRN, 2016.

FERREIRA, Yuma. A criança e a cidade: as transformações da infância numa Natal Moderna, 1890-1929. 2009. Dissertação (Mestrado em História) - Universidade Federal do Rio Grande do Norte, Natal, 2009.

GONÇALVES, João Felipe. Enterrando Rui Barbosa: um estudo de caso da construção de heróis nacionais na Primeira República. Estudos Históricos, v. 14, n. 25, p. 135-161, 2000.

HOUDEK, Matthew; PHILLIPS, Kendall R. Public memory. Rhetorical Theory, Oxford, p. 1-30, 2017.

JOBIN, Khalil. De ancoradouro à sal de espera: as obras de melhoramento do porto e a construção de uma Natal moderna (1893-1913). 2015. Dissertação (Mestrado em História) Universidade Federal do Rio Grande do Norte, Natal, 2015.

JOHNSON, Nuala. Cast in stone: monuments, geography and nationalism. Environment and Planning D: Society and Space, Thousand Oaks, v. 13, p. 51-65, 1995.

KNAUSS, Paulo. Herói da cidade: imagem indígena e mitologia social. In: KNAUSS, Paulo (coord.) Sorriso da cidade: imagens urbanas e história política de Niterói. Niterói: Fundação de Arte de Niterói, 2003. p. 47-81. 
KRAAY, Hendrik. Definindo nação e Estado: rituais cívicos na Bahia pós-independência (18231850). Topoi, Rio de Janeiro, v. 2, n. 3, p. 63-90, 2001.

KRAAY, Hendrik. Nação, Estado e política popular no Rio de Janeiro: rituais cívicos depois da Independência. In: PAMPLONA, Marco A.; DOYLE, Don H. (orgs.). Nacionalismo no Novo Mundo: a formação de Estados-nação no século XIX. Rio de Janeiro: Record, 2008. p. 329-354.

KULIŠIC', Marija; TUDMAN, Miroslav. Monument as a form os collective memory and public knowlegde. In: STANCIC, Hrvoje et al. (eds.). The future of information sciences: digital resources and knowledge sharing. Zagreb: University of Zagreb, 2009. p. 125-134.

LEACH, Edmund. Cultura e comunicação: a lógica da conexão dos símbolos. Lisboa: Edições 70, 1992.

LIGHT, Duncan; YOUNG, Craig. Public memory, commemoration and transitional justice: reconfiguring the past in public space. In: STAN, Lavinia; NEDELSKY, Nadya (eds.). PostCommunist transitional justice: lessons from 25 years of experience. Cambridge: Cambridge University Press, 2015. p. 233-251.

LOWENTHAL, David. Como conhecemos o passado. Projeto História, São Paulo, n. 17, p. 63-201, 1998.

MARCELINO, Douglas Attila. Os funerais como liturgias cívicas: notas sobre um campo de pesquisas. Revista Brasileira de História, São Paulo, v. 31, n. 61, p. 125-144, 2011.

MARCELINO, Douglas Attila. Rituais políticos e representações do passado: sobre os funerais de "homens de letras" na passagem do império à república. Tempo, Niterói, v. 22, n. 40, p. 260-282, 2016.

MARINHO, Márcia Maria Fonseca. Natal também civiliza-se: sociabilidade, lazer e esporte na Belle Époque natalense (1900-1930). 2008. Dissertação (Mestrado em História) - Universidade Federal do Rio Grande do Norte, Natal, 2008.

MEDEIROS, Gabriel Leopoldino Paulo de. A cidade interligada: legislação urbanística, sistema viário, transportes urbanos e posse da terra em Natal (1892-1930). 2017. Tese (Doutorado em Arquitetura e Urbanismo) - Universidade Federal do Rio Grande do Norte, Natal, 2017.

MELLO, Maria Tereza Chaves. A república consentida: cultura democrática e científica no final do Império. Rio de Janeiro: Editora da FGV: Edur, 2007. 
MENESES, Ulpiano T. Bezerra de. Pintura histórica: documento histórico? In: MENESES, Ulpiano T. Bezerra de et al. Como explorar um museu histórico. São Paulo: Museu Paulista/ USP, 1992. p. 22-24.

MENESES, Ulpiano T. Bezerra de. Do teatro da memória ao laboratório da história: a exposição museológica e o conhecimento histórico. Anais do Museu Paulista, São Paulo, n. 2, p. 9-42, 1994.

MENESES, Ulpiano T. Bezerra de. Cultura política e lugares de memória. In: AZEVEDO, Cecília et al. (orgs.). Cultura política, memória e historiografia. Rio de Janeiro: Editora da FGV, 2009. p. 445-463.

MITCHELL, Katharyne. Monuments, memorials, and politics of memory. Urban Geography, Abingdon v. 24, n. 5, p. 442-459, 2003.

NORA, Pierre. Entre memória e história: a problemática dos lugares. Projeto História, São Paulo, n. 10, p. 7-28, 1993.

OFFERLÉ, Michel. A nacionalização da cidadania cívica. In: CANÊDO, Letícia Bicalho (org.). $O$ sufrágio universal e a invenção democrática. São Paulo: Estação Liberdade, 2005. p. 343-361.

OLIVEIRA, Giovana Paiva de. De cidade a cidade: o processo de modernização de Natal 18891913. Natal: EDUFRN, 1999.

PAIVA, Diego Souza de. (Por)entre pedra e tela: a construção de uma memória republicana (Natal - 1906-1919). 2011. Dissertação (Mestrado em História) - Universidade Federal do Rio Grande do Norte, Natal, 2011.

PERALTA, Elsa. Abordagens teóricas ao estudo da memória social: uma resenha crítica. Arquivos da Memória, Lisboa, n. 2, p. 4-23, 2007.

PINHEIRO, Rosa Aparecia. Educação e modernização em Henrique Castriciano. Natal: EDUFRN, 2005.

POLLAK, Michael. Memória e identidade social. Estudos Históricos, Rio de Janeiro, v. 5, n. 10, p. 200-212, 1992.

RIBEIRO, Maria Eurydice de Barros. Os símbolos do poder: cerimônias e imagens do Estado monárquico no Brasil. Brasília, DF: Editora UnB, 1995. 
RÜSEN, Jörn. Razão histórica: teoria da história: os fundamentos da ciência histórica. Brasília, DF: Editora UnB, 2001.

RYAN, Mary. A parada norte-americana: representações da ordem social do século XIX. In: HUNT, Lynn. A nova história cultural. São Paulo: Martins Fontes: 1992. p. 177-209.

SEGALEN, Martine. Ritos e rituais contemporâneos. Rio de Janeiro: Editora da FGV, 2002.

SIMONINI, Yuri. Ribeira, técnica versus natureza: transformações em prol de um projeto de modernização (1860-1932). 2010. Dissertação (Mestrado em Arquitetura e Urbanismo) Universidade Federal do Rio Grande do Norte, Natal, 2010.

SIQUEIRA, Gabriela Fernandes de. Por uma "cidade nova": apropriação e uso do solo urbano no terceiro bairro de Natal (1901-1929). 2014. Dissertação (Mestrado em História) Universidade Federal do Rio Grande do Norte, Natal, 2014.

SOUZA, Eloy de. Costumes locais. Natal: Sebo Vermelho, 1999.

SOUZA, Itamar de. A República Velha no Rio Grande do Norte (1889-1930). Natal: EDUFRN, $2008 \mathrm{a}$.

SOUZA, Itamar de. Nova história de Natal. 2. ed. rev. e atual. Natal: Departamento Estadual de Imprensa, 2008b.

TEIXEIRA, Rubenilson Brazão. Da cidade de Deus à cidade dos homens: a secularização do uso, da forma e da função urbana. Natal: EDUFRN, 2009.

TUAN, Yi-Fu. Espaço e lugar: a perspectiva da experiência. Londrina: Eduel, 2013.

UHLE, Ana Rita. Operários da memória: artistas escultores do início do século XX e o concurso do monumento Glória Imortal aos Fundadores de São Paulo. Anais do Museu Paulista, São Paulo, v. 23, n. 2, p. 139-163, 2015.

VIANA, Hélder. A República e os conhecimentos do território norte-rio-grandense. In: BELLINI, Lígia; NEGRO, Antonio Luigi; SOUZA, Evergton Sales (orgs.). Tecendo histórias: espaço, política e identidade. Salvador: EDUFBA, 2009. p. 159-180.

Artigo apresentado em 03/10/2017. Aprovado em 14/11/2018.

\section{(c) BY}

